NBER WORKING PAPER SERIES

\title{
FOREIGN DIRECT INVESTMENT AND \\ KEIRETSU: RETHINKING U.S. AND JAPANESE POLICY
}

David E. Weinstein

Working Paper 5612

\author{
NATIONAL BUREAU OF ECONOMIC RESEARCH \\ 1050 Massachusetts Avenue \\ Cambridge, MA 02138 \\ June 1996
}

This paper was prepared for the NBER conference on "The Effects of U.S. Protection and Promotion Policies." I am grateful to the Ministry of Finance for allowing me to be a visiting scholar at the Institute for Fiscal and Monetary Studies during the summer of 1995 when this draft was prepared. While too many people helped me there to thank each of them individually, I want to especially thank Satoshi Ohuchi for arranging interviews. In addition to the Ministry of Finance, I would like to thank the Nomura Fund and the Japan Securities Research Promotion Foundation for financial support. Special thanks also go to Theresa Carney, Dennis Encarnation, Takuo Imagawa, Robert Lawrence, Ed Lincoln, Mark Mason, Paul Sheard, and Akihisa Tamaki for greatly improving my understanding of this topic. Jeff Bernstein, Takatoshi Ito, Hugh Patrick, Mark Ramseyer, and Klaus Wallner made extensive and invaluable comments on an earlier draft of this paper that were enormously helpful in preparing the final draft. Finally, I want to thank Robert Feenstra for suggesting I look at the "1\%" number in the first place. This paper is part of the NBER's project on International Capital Flows and NBER's research program in International Trade and Investment. I am grateful to The Center for International Political Economy for the support of this project. Any opinions expressed are those of the author and not those of the National Bureau of Economic Research.

(C) 1996 by David E. Weinstein. All rights reserved. Short sections of text, not to exceed two paragraphs, may be quoted without explicit permission provided that full credit, including (C) notice, is given to the source. 


\title{
FOREIGN DIRECT INVESTMENT AND \\ KEIRETSU: RETHINKING U.S. AND \\ JAPANESE POLICY
}

\begin{abstract}
This paper focuses on two issues. First, a reexamination of the data on the level of foreign direct investment (FDI) in Japan suggests that foreign firms sell five to six times more in Japan than is commonly believed. Previous studies severely underestimated the stock of FDI in Japan due to poor data. Second, after finding that even after adjusting for various factors the level of FDI in Japan is still low, the paper explores explanations for this phenomenon. A second main conclusion is that government tax and financial policy continues to inhibit foreign takeovers through the promotion of stable shareholding.
\end{abstract}

David E. Weinstein

Department of Economics

Harvard University

Cambridge, MA 02138 
For twenty-five years, the US and Japanese governments have seen the rise of corporate groups in Japan, keiretsu, as due in part to foreign pressure to liberalize the Japanese market. In fact, virtually all works that discuss barriers in a historical context argue that Japanese corporations acted to insulate themselves from foreign takeovers by privately placing shares with each other. ${ }^{1}$ The story has proved to be a major boon for the opponents of a neoclassical approach to trade and investment policy. Proponents of the notion of "Japanese-style Capitalism" in the Japanese government can argue that they did their part for liberalization and cannot be held responsible for private sector outcomes. Meanwhile, proponents of results oriented policies (ROPs) can point to yet another example of how the removal of one barrier led to the formation of a second barrier.

While agreeing with the basic conjecture that high levels of corporate ownership may work to deter takeovers in Japan, the argument presented here suggests that it is not cultural or institutional factors that produce corporate groups and high levels of stable shareholding, but rather conventional government policy. The focus on "conventional" policies is important. One does not need to rely on government encouragement and other non-binding mechanisms of Japanese industrial policy in order to understand the rise of Japanese corporate groups. The incentives to form these groups can, to a large degree, be traced to tax, regulatory, and other policies that are conventional in the sense that their impacts can readily be understood within a standard neoclassical economic paradigm.

The failure to recognize the role played by conventional policies in the formation of Japanese corporate groups has lead to tremendous frustration on both sides of US-Japan negotiations. The US claims that despite Japanese concessions, very little has changed. The Japanese, for their part, have grown tired of continual US complaints over sector after sector. To some extent, this is the result of a failure on both sides to face the facts. On the Japanese side, this

\footnotetext{
${ }^{1}$ See for example, Encarnation (1992), p. 76, Mason (1992), and Lawrence (1993).
} 
involves recognizing that they have created a financial system through tremendous government interventions based on dubious economic rationales. But the problem is not only a Japanese one. As this paper will try to demonstrate, the US position has been influenced by poor data and insufficient attention to the underlying government incentives to form distinctive Japanese corporate structures. This has led to a belief that standard principles of economics do not apply in the case of Japan and that US policy is continually hindered hidden informal regulations.

Considering the willingness of policymakers to believe that trillions of yen worth of securities changed hands because of government encouragement or a fear of potential foreign takeovers, it is not surprising that many in the US have decided that process oriented policies are not tenable and have favored results oriented policies (ROPs). Unfortunately for the proponents of these policies, it is not just academic economists who think that ROPs are bad economics, most Japanese do too. The current political climate in Japan strongly favors deregulation. The implementation of ROPs, however, requires greater governmental intervention which is likely to further entrench bureaucrats and generate future problems. As the most recent automobile parts negotiations revealed, the unpopularity of ROPs makes them very difficult to implement in practice.

All of this suggests that we reexamine the evidence in favor of ROPs and the notion that conventional policies are not important. The remainder of the paper therefore focuses on two issues. First, a reexamination of the data suggests that levels of FDI into Japan are not nearly as out of line with intemational levels as is widely believed. This conclusion is based on the fact that much of the data underlying the analysis of FDI into Japan is highly problematic. Second, after finding that even after adjusting for various factors the level of FDI in Japan is still low, the paper explores government interventions that may continue to inhibit foreign takeovers through the promotion of stable shareholding. 


\section{Data Issues}

One of the biggest problems in studying the level of FDI in Japan is that most of the Japanese data are highly flawed and the US data only give a very imperfect picture of the structure of foreign firms in Japan. Consider the case of one of the most widely cited pieces of evidence showing that Japan has inordinately low levels of FDI. In 1988, Julius and Thomsen presented international evidence on the level of FDI in various countries that showed, among other things, that while foreign firms in Japan only accounted for $1 \%$ of Japanese sales, foreign firms' sales in the US accounted for $10 \%$ of all sales in 1986 . The number was so striking that it soon became widely cited in academic articles [see, for example, Graham and Krugman (1989), p. 25; Graham and Krugman (1993); Graham and Krugman (1993), p. 16; and Lawrence (1993), p. 85] as well as at least one popular undergraduate text [Krugman and Obstfeld (1994) p. 162]. With many prominent economists citing this number, it was only a matter of time before it was influencing policymakers. Indeed, the first Clinton/Tyson Economic Report of the President (1994 p. 216) justified the US-Japan Framework Talks coverage of direct investment issues by citing the $1 \%$ figure.

The source of the $1 \%$ figure is a publication by the Japanese Ministry of International Trade and Industry (MITI), entitled Gaishikei Kigyo no Doko (Foreign-Owned Firm Trends). Usually MITI data are of the highest quality, but unfortunately this is a rare exception. The problem is that only about half of all firms surveyed actually responded. This $50 \%$ response rate probably overstates the coverage because the survey only covers affiliates that have more than $33 \%$ foreign ownership: far higher than the 10\% number reported in the US Survey of Current Business. Companies like Mazda are not counted as foreign affiliates in the Japanese data although they would be counted in the US data. Since foreign direct investments are often quite lumpy in the sense that a single acquisition can move the aggregate numbers substantially, omissions like Mazda, which is one quarter owned by Ford, can create a very different picture of the level of foreign presence in a market. For example, due to the Mazda omission, even if the MITI response 
rate for other firms in transportation equipment had been $100 \%$, they only would have reported around $1 / 3$ of the sales of companies that are more than $10 \%$ foreign owned.

Furthermore, the response rate varies year to year and sector by sector making it difficult to interpret longitudinal and cross-sectional comparisons of the importance of foreign firms in Japan. The differences in reporting rates are likely to be quite large across sectors. While MITI does not report response rates by sectors, a similar survey conducted by Toyo Keizai, found that response rates differed by as much as $100 \%$ across sectors, with non-manufacturing reporting significantly less than manufacturing. All of this suggests that great caution should be used in inferring much about the distribution of FDI from the MITI numbers.

Many studies have focused on the inflows or levels of foreign capital stocks in Japan as an alternative to the MITI survey results. Unfortunately, it is not just the MITI numbers that vastly understate the level of FDI in Japan: the numbers published by the Bank of Japan and the Ministry of Finance are also inaccurate measures of FDI flows and stocks relative to the FDI numbers published for the US in the Survey of Current Business. ${ }^{2}$ It is worth first noting, however, that one factor in the MOF numbers tends to make them appear larger than the BOJ numbers. The MOF statistics are based on foreign firm notifications about future investments, not actual investments. This means that the numbers will overstate actual investments somewhat because firms that notify the MOF that they will invest but then cancel their plans will not be counted. Hence in 1992 the MOF reported that inward FDI was $\$ 4.1$ billion but the Bank of Japan numbers used in the balance of payments statistics reported only $\$ 2.7$ billion of investments. The MOF numbers are not necessarily larger than the BOJ numbers on a year-to-year basis, however. If a firm notifies in one year but conducts all or part of the investment in the subsequent year, then the MOF will record the investment in the year of notification but the BOJ will record the investment when it actually occurred.

The rest of the biases in the MOF and BOJ numbers make estimating of the capital stock of foreign firms almost impossible. First, the MOF numbers do not count investments of less than

\footnotetext{
${ }^{2}$ The analysis of this BOJ and MOF data is drawn from Matsuoka and Rose (1994).
} 
$¥ 30$ million and the BOJ leaves out investments of less than $¥ 5$ million. Based on the size breakdown of foreign firms in Japan given by Gaishikei Kigyo Soran [GKS] (General Survey of Foreign Firms), a source we will examine later, this means that approximately $1 / 3$ of all firms are left out of the MOF numbers and $10 \%$ are left out of the BOJ figures. A bigger problem stems from the fact that FDI arising from retained earnings, the opening and expanding of branches, and the purchase of land do not appear in the MOF statistics. ${ }^{3}$ Since the vast majority of the increase in the FDI stock by US accounting methods occurs because existing foreign firms expand operations, the difference in accounting in the Japanese numbers serves to lower the Japanese numbers by a factor of three or four relative to the US numbers. In addition, loans were not counted until 1985 and acquisition of unlisted stocks is not included which further pushes down the numbers.

On top of these distortions, the MOF reports of aggregate FDI stocks are calculated by summing up nominal dollar investments over time. In other words, if a foreign firm made a \$1 million investment in Japan when the exchange rate was $¥ 360 / \$ 1$ then that investment would still count as $\$ 1$ million today in the aggregate stock numbers despite the fact that exchange rate movements alone should have increased it by a factor of four. In fact, simply adjusting the reported MOF numbers by a price index, the exchange rate, and the assumption that foreign firms' capital stock grew at the same rate as the domestic Japanese capital stock would increase the reported level of Japan's FDI stock from $\$ 26$ billion in 1992 to over $\$ 100$ billion. Indeed, this number probably significantly understates the level of assets under the control of foreign corporations because it does not include assets purchased by borrowing or by funds supplied by Japanese partners. Given these considerations and the others mentioned, the stock of FDI in Japan could be as much as 10 to 12 times higher than the reported levels. This is not to say that it is likely that the numbers are that high, only that the data are so bad that it is not unreasonable to think that the official numbers are off by an order of magnitude.

Given these data problems, various authors have tried to use US numbers as an indicator of the level of FDI in Japan. The numbers from the Bureau of Economic Analysis are clearly superior

\footnotetext{
${ }^{3}$ Land does appear in the BOJ numbers.
} 
to the Japanese numbers, but the problem with using US numbers as a proxy for total FDI is that the level of FDI in Japan is very imperfectly correlated with the level of US FDI in Japan. US firms account for $46.5 \%$ of all foreign firms operating in Japan, but the distribution of US firms differs significantly from the distribution of non-US affiliates. Relative to other foreign affiliates, US firms are more heavily concentrated in manufacturing than in services, but there is enormous variation across sectors. For example, US firms are underrepresented in banking and in petrochemicals, where only $14 \%$ and $6 \%$ of all foreign affiliates are from the US. On the other hand, and they are vastly overrepresented in sectors like precision instruments and information services where over $75 \%$ of all foreign affiliates are US firms. This makes it extremely difficult to draw inferences about the overall level of FDI in a sector from the US distribution.

All of this raises the question of whether it would be possible to obtain a more accurate estimate of the stock of FDI in Japan. As the previous analysis has suggested, the government data are so poor that all one can conclude is that the actual level of sales by foreign affiliates or FDI is probably somewhere between 4 and 12 times larger than the reported levels. Fortunately, there are two private sources of FDI data in Japan that are significantly better than the government sources: one published by Nihon Keizai Chosakai and the other by Toyo Keizai (GKS). The coverage is similar and we will focus on the latter.

In 1992, Toyo Keizai conducted a survey of 3402 foreign companies in Japan (about $30 \%$ more than the MITI source) and had a response rate of $82 \%$. The data contains a fairly large number of missing observations, especially for smaller companies, so I built a sample containing foreign firms in Japan that employed over 99 employees. This yielded 533 firms, but even in this sample there were 157 firms that did not report sales numbers for $1992 .{ }^{4}$ Using only the firms for which we had data, the total sales of foreign affiliates stood at $¥ 40.3$ trillion or $5.3 \%$ of all gross output in Japan: over five times higher than previously published numbers! $!^{5}$ To obtain an estimate of the sales of the 105 firms for which we had employment but not sales data, I regressed log sales

\footnotetext{
${ }^{4}$ Most firms in Japan do not have fiscal years that correspond to calendar years so, in general, the fiscal year that most overlapped with the calendar year was chosen.

${ }^{5}$ Figures do not include construction because no firms reported numbers to Toyo Keizai.
} 
on log employment and used the estimated coefficients to estimate the sales for the firms that only had employment data. ${ }^{6}$ Adding in these firms raised the total of foreign sales to $¥ 43.0$ trillion or $5.6 \%$ of all sales. If we assume that the 1243 firms employing 99 or fewer workers have sales linearly distributed between zero and the sales of the smallest firm in my sample, then this implies that foreign firms sell $5.7 \%$ of all sales in Japan. These numbers still underestimate the true level of sales because of the $82 \%$ response rate to the questionnaire. For example, some large firms like Nippon ABS or Suzuka Fuji Xerox, with close to 1200 workers apiece, were left out of the sample. Adding these firms in might raise the number still further.

It is worth remembering that even if foreign firms' share of the Japanese market stands at 6 percent, it still is lower than that in most other OECD countries by a factor of two or three. Furthermore, because of historic restrictions on majority-owned affiliates, the stock of majority owned foreign firms is even more out of line with international averages. However, given that the stock of FDI is highly correlated with new inflows which, in turn, are largely are a measure of the expansion of existing firms, it is not surprising that recent Japanese liberalizations have not brought stocks in line with international averages. Furthermore, considering Japan's high corporate tax rate and the high cost of land, labor, utilities, and other non-tradables, it is easy to come up with a large list of other reasons why multinationals often choose other countries in which to locate foreign affiliates.

Probably the most controversial reason why foreigners do not invest in Japan has to do with the difficulty of conducting takeovers in Japan. Mergers and acquisitions constitute one of the major mechanisms through which US firms enter foreign markets, and the difficulty of conducting takeovers in Japan has often been argued to be an important factor in understanding why foreign penetration of Japan still remains lower than in most OECD countries. More specifically, it is often argued that the large amounts of shares held by Japanese corporate groups act as a major impediment to FDI. Indeed, there have been an enormous number of anecdotes that have piled up over the years suggesting that the large number of shares held by Japanese corporate groups, or

\footnotetext{
${ }^{6}$ Manufacturing and non-manufacturing firms were treated separately throughout.
} 
keiretsu, work to make takeovers exceedingly difficult in Japan. One approach to testing this hypothesis is to use econometric evidence that controls for various factors and to see if sectors with high keiretsu shares have lower levels of FDI. Unfortunately, given the crudeness of the data and the complexity of the theories, the results are often very difficult to interpret. Furthermore, this approach leaves open the question of why these shareholding patterns have emerged in particular sectors. Economists have made great contributions to the Japanese industrial organization literature arguing that many of these seemingly irrational arrangements may in fact be efficient, but these discussions are somewhat unsatisfying because the theories have difficulty explaining why there is so much variation in corporate ownership of securities over time.

The remainder of this paper will ignore most of what has been written on keiretsu in order to highlight the role played by conventional government interventions. Two caveats are in order. First, the government regulations presented here are by no means the only ones present or relevant: to catalog all such regulations would result in a book (or books) instead of a paper. ${ }^{7}$ Instead, I have tried to highlight the policies I feel are most important to the debate. My focus on the market for corporate control stems from the fact that corporate takeovers are a major mechanism by which US firms conduct FDI. Second, my decision to ignore most of the economic and sociological contributions to the understanding of Japanese corporate groups is not a product of my thinking that they are unimportant, but rather because I want to focus on the regulatory issues. ${ }^{8}$

\section{The Ownership Puzzle}

During the late 1960's and early 1970's Japan substantially liberalized its controls on FDI. At roughly the same time there was a substantial rise in the corporate ownership. It is therefore not surprising that these two phenomena were linked by both Japanese and foreign researchers. Just as

\footnotetext{
${ }^{7}$ For example, Ito (1992) has one of many books in Japanese on deregulation. His chapter on financial market deregulation focuses on the regulation of interest rates, bank deposits, consumer credit, banking hours, and electronic transfer fees. These are all likely to have very important impacts on consumers, but I do not discuss them here because their impact on corporate ownership is less clear.

${ }^{8}$ Readers interested in learning more about sociological and economic approaches should see Gerlach (1992) and Aoki and Patrick (1994).
} 
with the $1 \%$ number, a consensus was achieved that the rise of cross-shareholding in Japan was a product of FDI. Consider the following passage from Viner (1988) who is representative of a much wider literature:

In 1971, an amendment to the Securities Exchange Law introduced a system of notification for takeover bids and, in 1972, Bendix Corporation made a tender offer for part of the equity in a small firm (Jidosha Kiki). These events prompted Japanese corporations to consider measures that would prevent foreign firms from initiating hostile takeovers of domestic companies. Thus, it was decided that mutual shareholding, if established on a more widespread basis, could render foreign takeovers virtually impossible in many cases. With this in mind, hundreds of corporations (with unofficial Ministry of Finance encouragement) that were not members of a keiretsu systematically expanded their mutual shareholdings. Companies within keiretsu increased their mutual shareholding to the legal limit. As a direct result...the percentage of shares held by corporations rose $12.7 \%$ [in just one year, 1971-72].

In terms of the history of thought on Japanese keiretsu, this quote is fascinating because virtually every verifiable fact mentioned is wrong! First, MOF data reveals that the percentage of shares held by corporations rose $9.7 \%$ not $12.7 \%$ : an overestimate of $31 \% .{ }^{9}$ Second, the statement "companies within keiretsu increased their mutual shareholding to the legal limit" is correct only in the sense that more than one company was at the legal limit in 1972. In a sample of presidents' club members constructed using 1972 data from KKS, city banks could have hit their legal limit of $10 \%$ ownership 124 times. This actually only occurred in three cases. Although it is difficult to test the same hypothesis for non-financials, considering that most of them held less than $1 \%$ of the shares of the other companies in the group, it is highly unlikely that the legal cross-shareholding limit was binding for many of them either. ${ }^{10}$

What about the role of government? It is true that Japan passed its first takeover law in 1971, but as Ramseyer (1987) has argued, takeovers were not illegal before the law, there just were no rules governing them. The 1971 law simply created rules governing takeovers. Indeed, one of the reasons for the passage of the law was to make takeovers, especially by foreigners, more difficult [Adams and Hoshii (1973), p. 190]. In this sense, Viner's argument is the

\footnotetext{
${ }^{9}$ TSE data indicates the increase was even smaller: only $7.6 \%$. See footnote 12 for an explanation of the two data sources.

${ }^{10}$ The important legal factor limiting ownership for non-financials is that a subsidiary cannot own shares in a parent.
} 
equivalent of arguing that monopolies could not have existed in the US until the Sherman Antitrust Act. Furthermore, neither the legal change nor the Bendix bid could possibly have driven most of the cross-shareholding because they occurred too late. Figure 1 shows the evolution of equity ownership in Japan. It is clear that much of the increase in financial and non-financial corporate ownership occurred in the period between 1965 and 1971, long before either the legal change or the takeover bid. ${ }^{11}$ In fact, ownership by financials, the companies at the core of financial groups, seems to follow a generally smooth upward trend between 1968 and 1988 . Finally, the statement that the MOF "encouraged" cross-shareholding suggests that major realignments in the structure of Japanese capital markets can be achieved through unconventional means. However, as we will soon see, the main problem with focusing on MOF encouragement is that it obfuscates the fact that a very real intervention occurred.

One explanation for the rise in cross-shareholding in the late 1960s, often suggested by other authors, is that the fear of foreign takeovers arising from future liberalization generated the increase. As Mason (1992) documents, Japanese government and industry leaders placed the blame for the increase in shareholding squarely on fears of foreign entry following market liberalization. Unfortunately, for those trying to understand the phenomena, the hypothesis is difficult to test because it is predicated on the fear of an event that never happened. But here again the numbers raise serious questions. First, in 1966, corporations already owned over half of all outstanding shares, which raises the question of why it was that Japanese firms felt vulnerable to takeovers when corporations owned $55 \%$ of their shares but safe at $66 \%$. Certainly it is possible that the increase in shareholding was due to the increase in holdings by companies who had less than $50 \%$ of their shares in the hands of stable shareholders. However, this raises another puzzle concerning why it was that before the threat of liberalization, corporate ownership was so high. Second, it is hard to see how something as trivially small as FDI could drive enormous shifts in ownership. For most of this time period and even after liberalization, the level of FDI was so low that had the entire inflow gone towards the purchase of equity, foreign ownership of Japanese

\footnotetext{
${ }^{11}$ Total corporate shareholding is relatively flat over the earlier period because of the disappearance of investment trusts and securities companies as large holders. The reasons for their demise will be discussed later.
} 
securities would have only increased by a few tenths of a percentage point. As one can see from Table 1, foreign ownership of Japanese securities increased by only 0.9 percentage points over this time period. ${ }^{12}$ It seems unlikely that in response to this modest increase in foreign ownership Japanese corporations bought up $11 \%$ of the market. Indeed, this enormous response is even more puzzling considering that corporate ownership today is only 5 percentage points higher than was in 1975 even though the share of foreign ownership has doubled. ${ }^{13}$

It is not just the data that makes it difficult to believe that the rise in corporate shareholding in Japan was in response to foreign takeovers. In order to believe that Japanese firms were good takeover targets one must either believe that Japanese managers were inferior to foreign managers or that Japanese firms were undervalued. However, considering the fact that between 1965 and 1975 the return on the TSE index was around 100 percentage points higher than the return on the S\&P 500 before factoring in currency adjustments, it is hard to argue that Japanese firms were systematically badly managed from a shareholder standpoint. Similarly, it also seems doubtful that the only people who could have appreciated the fact that Japanese stocks were undervalued were foreigners.

All of this suggests that we dig a little deeper into the data. The following sections explore the policies that explain why the largest corporate holders of equity in Japan - insurance companies, banks and non-financial enterprises - decided to invest so heavily in securities.

\section{Insurance Companies}

It turns out that the reason for the rise of Japanese insurance industry is easy to locate: the Japanese tax code. The major tax advantage offered to life insurance companies is that they have

\footnotetext{
12 The data in Figure 1 is not directly comparable with that in Table 1 because the TSE (the source for figure 1) does not include shares listed on the over-the-counter market while the MOF numbers do until 1966. Prior to the creation of the second section of the TSE in 1961, this creates some big differences in the numbers, especially for non-financial holding. This is why there is a (spurious) slight upward trend in non-financial holdings in Figure 1 prior to 1961 which does not appear in the numbers shown in Table 1. Figure 1 was based on TSE numbers because the TSE series start earlier and, after 1985, are more comprehensive than the MOF numbers.

${ }^{13}$ In fact, foreign portfolio investment in Japan exceeds that in the US.
} 
had a monopoly in tax free individual investment plans. Premiums paid into life insurance policies or for pension plans administered by life insurance companies are tax deductible up to $¥ 25,000$, $50 \%$ deductible for the next $¥ 25,000,25 \%$ deductible for the next $¥ 50,000$, and then fully taxable afterwards. Thus, a typical taxpayer has a strong tax incentive to purchase life insurance or pension policies up to $¥ 100,000$ per year to a life insurance pension fund. Similarly, there is an additional tax incentive that provides a tax deduction of a $¥ 15,000$ on contributions of $¥ 20,000$ for property and casualty insurance. ${ }^{14}$ These numbers, however, underestimate the historical importance of the tax incentives. Inflation has largely eroded the value of this subsidy over the years. For example, in 1961 , a taxpayer that contributed $¥ 60,000$ to an insurance type pension plan could deduct one half of his total payments from his taxable income. Considering that $83 \%$ of taxpayers in that year had incomes of less than $¥ 500,000$, these subsidies made insurance an obvious channel for investment funds. 15

Given the absence of IRA's and most other forms of tax free investments in Japan, the Japanese tax code made insurance plans the preferred individual investment vehicle for many Japanese, and the renowned savers of Japan poured money into them. ${ }^{16}$ In 1993, approximately one quarter of all Japanese financial wealth was tied up in insurance policies. Indeed, the value of life insurance contracts in 1990 was 4.75 times larger than national income. Relative to the rest of the world, this is an enormous number. For example, in the same year, the next highest country was Korea at 2.7 times national income, with most of the west far further behind. ${ }^{17}$ The reason for the high levels of insurance is that virtually all Japanese policies contain maturity benefits. In fact, death benefits comprised less than a third of all life insurance payments in 1993. In contrast, maturity payments and lump sum annuities accounted for $62 \%$ of all payments, with payments for hospitalizations and operations accounting for most of the remainder.

\footnotetext{
${ }^{14}$ An Outline of Japanese Taxes, 1994, p. 53.

${ }^{15}$ An Outline of Japanese Taxes, 1961, p. 208.

${ }^{16}$ The big exception was tax-free postal savings accounts or maruyu which were abolished in the late eighties. We will turn to the role of postal savings later in the paper.

${ }^{17}$ ZKTG Hoken p. 76. For reference the numbers for other countries were: US, 2.15; Canada, 2.4; France, 2.2; UK, 1.3; Former West Germany, 1.0.
} 
Japanese households have therefore chosen to save primarily through two types of investment vehicles. Either they have invested through insurance companies or they put their money in bank or postal accounts. While this may help explain why Japanese buy so much insurance, it doesn't explain why Japanese insurance companies buy so much equity. For example, stock holdings only comprised $11.5 \%$ of US insurance firms' assets in comparison with $20.3 \%$ in Japan. US firms invest very heavily in public and private bonds, but these only constituted about $10 \%$ of Japanese holdings. Much of the remainder of insurance companies' assets is comprised of loans and foreign securities. This makes Japanese insurers look quite similar to banks. In fact, the returns on endowment policies (i.e. policies with a maturity value) offered by insurers and bank time deposits are quite close in Japan. This contrasts sharply with the West where the return on deposits is generally substantially higher [Bronte (1982), p. 102].

In order to understand equity holding by insurance companies, we need to examine the pattern of ownership at the firm level. Table 2 is a matrix showing the pattern of ownership among presidents' club members of the Mitsui group in 1993. The presidents of all of these firms attend regular meetings which do not involve the planning of collective strategy so much as the sharing of information. The elements in the table indicate the percentage of shares of the row company owned by the column company. One of the striking features of this table is that for 15 out of the 25 stock companies total group ownership stands at less than $20 \%$, and in no case is more than $40 \%$ of the equity of a company held by the entire group. With typically around $80 \%$ of group member equity held by non-group holders, it is hard to argue that financial keiretsu have "unassailable control over all outstanding equity." 18 The issue seems not to be why keiretsu hold so many shares, but rather why it is that banks, insurance companies, and firms, in general, tend to buy and hold on to so much equity.

A second interesting feature of this table is that despite the common tendency to call Mitsui a "bank centered group" the largest single shareholder is not a bank but a life insurance company. The Mitsui group is not alone in this respect. In four out of the six largest groups, the largest single

\footnotetext{
${ }^{18}$ Encarnation (1992), p. 75. Encarnation is actually referring to the Mitsubishi keiretsu, whose ownership structure
} was quite similar to Mitsui. 
shareholder is an insurance company. Not only are insurance companies very large holders of equity within Japanese financial groups, their holdings are relatively stable. In 1980, for example, Mitsui Life and Mitsui Fire and Marine (Formerly, Taisho Fire and Marine) held 3.85\% and 1.99\% of the presidents' club member stocks in comparison to $3.72 \%$ and $1.61 \%$ today. This pattern of "stable shareholding" can be seen in aggregate data as well. Although insurance companies held $17 \%$ of all equity in Japan, these firms only accounted for $1 \%$ of all sales and purchases [TSE]. By contrast, foreigners, with less than half the level of equity ownership, executed thirteen times more sales and purchases. The shareholding patterns of Japanese insurers is closely connected to the patterns of purchases of insurance in Japan. Table 3 presents the results of a 1993 American Chamber of Commerce survey of presidents' club members. The data clearly show that the vast majority of property and casualty insurance for each of the presidents' club members was purchased from the insurance company that had the largest shareholding in the company. Unfortunately, similar data are not available for the life insurance sector, but discussions with both Japanese and US members of the industry suggest that it is likely that a similar picture would emerge if the data were available.

McKenzie (1992) and others have argued that one of the primary functions of this stable shareholding is to make it more difficult for another company to take over the insurance purchaser. In other words, Japanese insurance companies do not simply sell insurance; they also sell their willingness to remove a certain percentage of shares from active trading. The reason why they offer both products stems from their inability to compete effectively in the insurance market. Property and casualty insurance, in Japan, is not sold through brokers but rather through case agents who typically only handle one or two insurance companies' products. These case agents are often owned by the companies that purchase the insurance. This means that if management decides to use a particular insurance company, they can influence the case agent to carry only that insurers' policies. For automobile insurance these agency commissions typically account for $17.9 \%$ of the total premium cost even for policies sold to repeat customers. ${ }^{19}$ In the US, $60 \%$ of automobile

\footnotetext{
${ }^{19}$ The description of the automobile insurance market is taken from Diamond Report.
} 
insurance is sold through non-agency channels like direct marketing or telemarketing which largely eliminates these middlemen. This largely accounts for the fact that the expense ratio (the share of the insurance premium that does not cover the actuarial risk cost) is fourteen percentage points higher in Japan than in the US.

However, it is doubtful that it is simply the absence of sufficiently diligent antitrust enforcement that makes this system tenable. Stable shareholding is costly for insurance companies, and in a free market, there would be an incentive for these insurers to offer cheaper insurance to companies that did not require the insurer to take out big equity positions. Here, government regulation plays an important role. In the non-life sector this regulation has largely arisen from the government's exemption of the Premium Rating Agency (PRA) from the Anti-Monopoly Law. The PRA sets uniform rates for motor vehicle, compulsory motor liability, fire, earthquake, and accident insurance. ${ }^{20}$ Ostensibly, this agency exists to make sure that price competition does not drive insurers into bankruptcy, but the net effect is to enforce high prices in the market.

Furthermore, the Ministry of Finance historically has not been very receptive to the development of new insurance products. Typically the approval process for new insurance products requires that the developer make public virtually all of the relevant data on the product. Since this means that companies that do not innovate can enter the market without paying for much of the research and development, the returns to innovation are largely eliminated. ${ }^{21}$ This helps explain why in the automobile insurance sector, there are no differences in policy rates based on age or driving history.

In life insurance markets, the situation is somewhat different. Here, again, there have been efforts to set fees above market rates, but firms have been able to offer investors guaranteed investment contracts (GICs). These contracts offer investors a guaranteed minimum return on their insurance policies and are one of the major reasons why many Japanese insurers are currently in deep financial trouble following the recent decline in stock prices. Theoretically, these investment contracts should be the dimension along which competition should wipe out the rents and therefore

${ }^{20}$ Carrol, p. 15.

${ }^{21}$ Diamond Report. 
the stable shareholding. McKenzie (1992) has argued that competition in insurance is stifled by extensive sharing of information as well as the tacit cooperation of MOF in an insurance cartel. The problem with this argument is that many industries are characterized by extensive information sharing and are quite competitive. For example, one can easily find out the prices of all computers sold through catalog stores, but one would hardly consider that sector uncompetitive. Indeed, considering the homogeneity of life insurance, one should expect it to be very competitive. As for the ability of MOF to enforce a cartel in insurance, while MOF did restrict entry, it is hard to see how it could prevent life insurance firms that had agreed to keep returns low ex ante from obtaining high returns ex post. In general, cheating seems to have plagued other Japanese attempts to form cartels. For example, Weinstein (1995) examined cartels formed by the Ministry of International Trade and Industry and found that virtually all of them were failures. Why should insurance be any different?

Basic cartel theory tells us that in order for a cartel to be sustainable there must be a credible enforcement mechanism to ensure that those firms that violate cartel prices will not reap a gain. In all likelihood, none of MOFs regulations are sufficiently rigid or enforceable to maintain a cartel in insurance. A more reasonable place to look for an enforcer is the Ministry of Posts and Telecommunications (MPT) which administers the vast postal insurance fund and postal savings system. In 1993, the value of funds in the postal insurance plan equaled just over $¥ 74$ trillion: equal to roughly half of the assets held by Japan's 27 private sector life insurance firms. This makes the Japanese post office the world's largest provider of life insurance, with the biggest Japanese company, Nippon Life, being less than half as large. In addition, when measured in deposits, the Japanese post office is also the world's largest bank. At the end of 1993, the value of deposits in the Japanese postal savings system stood at $¥ 184$ trillion which accounts for about a quarter of all deposits in Japan.

One is tempted to think of the postal savings, insurance, and pension plans as vestige of Japan's past development strategy. The system was founded around one hundred years ago during a time when few banks existed and the government wanted to channel savings into productive 
purposes. However, far from dying a graceful death, the numbers demonstrate that funds under the administration of the Japanese post office have been growing at a tremendous rate. Most striking is postal pensions which have increased from a forty year low of $¥ 1.3$ billion in 1980 to over a trillion yen today. Funds in the Japanese postal insurance fund have increased as well: more than doubling between 1987 and the end of 1993. Finally, the postal savings system has succeeded in increasing its deposits by $¥ 100$ trillion over the last ten years. No one can really justify the postal savings system on efficiency grounds, and yet it continues to grow.

What is important to recognize about this system is that the rates set by the post office on its pension and insurance plans are not determined by the returns on the investments of government financial institutions. According to Japanese law, the rates set on postal accounts must reflect current market rates. In effect, the MPT (often in conjunction with the MOF) sets rates by surveying private sector rates and then choosing a rate that maintains its "competitiveness" in the market. If private rates are high then postal rates are high and if private rates are low, then postal rates will be low as well. The MPT is intent on maintaining a certain share of the market, and quite often the returns to postal accounts are higher than those in the private sector. This eliminates much of the gain that could be realized by private sector firms in the market. They can compete against each other, but if one firm's market share starts to encroach on that of the postal system the postal rates will move to eliminate the firm's competitive advantage. By always setting a "competitive price," the post office can eliminate the gains from competition, thereby providing a credible enforcement mechanism to support collusion in Japanese financial markets.

Indeed, the Japanese debate on the privatization of the postal savings system demonstrates the fact that the postal savings system exerts an anticompetitive influence on banks. There have been a number of suggestions to break the postal savings system up and create around ten banks. Regional banks, in particular, have strongly opposed this on the grounds that these new banks would create fierce competition. But, of course, this fear is only warranted if current rates on deposits are below competitive levels. 
By keeping rates on deposits low either through stifling competition or by direct regulation of deposit rates (which remained in force throughout much of the postwar period), the government increased incentives for funds to be invested through insurance companies. These regulations may have increased the incentives for stable shareholding by Japanese insurers. In other words, it may be government policies, not Japanese business practices, that are the problem.

\section{Bank-Firm Links}

It is not just insurance companies who face heavy government interference; Japanese banks also must compete with the government. The economics of a system in which banks are both large lenders and shareholders in firms while firms also hold large shares in banks has been analyzed extensively elsewhere (see for example, Sheard (1994) and Aoki and Patrick [1994]), and hence it makes little sense to go through all of the arguments about the costs and benefits of this type of corporate governance structure here. This section will therefore focus on some of regulations and laws that help support this structure.

A striking feature of Table 2 is that while there is very little cross-ownership of shares among manufacturing firms, these firms own substantial amounts of shares of the financial firms. Out of 88 possible cross-shareholds among manufacturers, cross-shareholding only occurred eight times and most of these shareholds involved less than $1 \%$ of the firm's equity. Adding in nonfinancial, non-manufacturing firms raises the ratio of actual cross shareholds relative to total possible cross-shareholds to $16 \%$ : slightly higher but still quite low. In fact, it is quite clear from the table that virtually all cross ownership of corporations takes the form of financial firms taking large positions in non-financials and these non-financials taking large positions in the financials. While a manufacturing firm was one of the top twenty shareholders of another manufacturer only $4 \%$ of the time, all manufacturers held shares in all the financials, and manufacturers were the top twenty shareholders of their group banks in $28 \%$ of the cases. These data suggest that crossshareholding is largely a phenomenon among financials or between financials and non-financials. 
While non-financials often hold shares in other non-financials, the amount of reciprocation is actually quite small.

Once again the tax code plays an important role in these relationships. While the only form of tax deductible investing open to Japanese households has traditionally been through insurance policies, a major source of investment funds arises from private corporate pension funds. Private pension funds are one of the largest single holders of shares in the US but they account for less than $10 \%$ of all shareholding in Japan. The primary reason for this difference is a 1962 amendment to the Tax law that created tax advantages for the formation of pension plans [Adams and Hoshii (1972) p. 110]. Under this amendment, firms were able to create tax free pension plans, funded either by the employer or the employees, if the money was invested either through insurance companies or trust banks. This tax law is one of the principle reasons why trust banks were able to become not only major lenders to firms but also major shareholders.

However, regulation has exerted a fairly important restraint on the ability of these trust banks to compete. In order to obtain the tax benefits, trust banks and insurance companies that manage pension funds must invest in very specific types of assets that are determined by the MOF. Ostensibly the objective of these restrictions is to prevent pension money from being invested in risky assets, but a subsidiary impact is to impose a fair degree of homogeneity on the portfolio composition and therefore the return. Investments must follow the 5-3-2 rule: 50\% of the money must be invested in secured bonds or loans, $30 \%$ may be invested in stocks, and $20 \%$ in real estate or real estate trusts [Adams and Hoshii (1972) p. 110]. These restrictions make it difficult for banks and insurance companies to offer differing returns, and as we have seen before, the lack of competition in financial product markets often leads to stable shareholding. Indeed in 1980, for example, the return on large pension funds managed by trust banks varied (after commissions) by less than 1 percentage point [Bronte (1982), p. 238].

The impact of these regulations was probably compounded by taxes on securities transactions, mandatory minimum fees for brokerage services, a bond underwriting cartel, restriction of international capital movements, and restrictions on the opening of bank branches. 
These regulations tended to favor debt as a source of outside financing and tended to reinforce relational banking in Japan. ${ }^{22}$ Japan's prohibition of holding companies following the dissolution of the prewar zaibatsu probably also enhanced the position of banks within Japanese corporate groups. Thus, Japanese banks, with both the capital and the absence of restrictions on corporate shareholding below a certain level, were in a relatively good position to monitor Japanese corporations. As monitors, it is not surprising that certain Japanese banks took large equity positions in firms that they sought to monitor and tended to hold on to these positions.

However, it is also important to remember that the same argument explaining stable shareholding in insurance markets also works in lending markets. A tremendous amount of the money collected in the postal savings system is pumped back into the economy through loans from various government institutions. Government banks like the Japan Development Bank and the Export-Import Bank are well known, but these are only the tip of the iceberg. There are over a hundred semi-governmental financial institutions operating in Japan [Bronte (1982), p. 149]. In 1991, these public financial institutions accounted for $31 \%$ of all lending in Japan [BOJ (1994), p. 250]. Considering that these financial institutions set rates in order to maintain a certain share of the market, it is not inconceivable that these institutions diminish the incentives of banks to compete through lower interest rates. While this impact is probably most pronounced in small business lending and agriculture, industrial lending by public institutions is by no means limited to these sectors.

Explaining why it is that non-financials are such large holders in financials is more difficult. Sheard (1994) finds that while non-financials own less than a quarter of all outstanding equity, about $58 \%$ of all of the equity in his sample of 21 banks is held by non-financials. Nonfinancials have a particularly large equity stake in the firms that supply them with capital. Considering that banks make up about $1 / 6$ of all of the equity on Japanese exchanges, this implies that non-financial ownership of non-financial firm equity is probably around $17 \%$, which is not very different from average total non-financial ownership in the US. In other words, most of the

${ }^{22}$ The bond cartel and the restrictions on international capital flows disappeared by the early 1980s. The tax on securities transactions was reduced in 1989. 
relatively higher level of non-financial ownership of equity is due to the main bank system. Sheard argues that non-financials buy and hold on to bank shares in order to provide a collective enforcement mechanism that ensures that banks perform their role as monitors. This implies that the same regulations that created the main bank system may also have increased shareholding by non-financials as well.

It is also possible that interest rate regulation may play a role here as well. Interest rate regulations on bank loans created the "compensating balance" system in Japan. In order to circumvent interest rate restrictions, banks required that firms that received loans deposit a sizable portion of that loan with the bank. These compensating balances raise the effective interest rates on loans. It is not inconceivable that in order to get loans in a capital rationed market, some firms also agreed to become stable shareholders in the banks as well.

\section{Vertical Groups}

Just as Japanese financial groups have recently attracted a tremendous amount of attention, vertical groups, too, have often been the center of trade and investment friction. Ownership by these non-financials accounts for fully one third of all corporate ownership in Japan. While the rise of this ownership is often blamed on foreign investment, the development of these groups is also quite closely linked to conventional policies. Vertical groups are comprised of an assembler who is

surrounded by a large number of smaller suppliers that are technically independent. There is a fairly large body of literature examining these relationships in terms of their efficiency and social origins. Once again, we will focus on the government regulations that have helped produce this system.

In order to understand the government regulations, we need to be clear about what we are explaining. The most common source used for analyzing these manufacturing groups is the Dodwell Marketing Consultant's Industrial Groupings in Japan. With only around 40 groups listed, that source underestimates the importance of these groups in Japan. Table 4 is drawn from 
Toyo Keizai's Kigyo Guruupu which contains data on over 1000 manufacturing groups. ${ }^{23}$ About half of all related firms in Japan typically appear to be located either in the same industry as the manufacturer or in distribution. As various authors have noted, these relationships are fairly stable. Three quarters of the 8,200 related firms for which we have detailed data were in the same manufacturing group ten years earlier.

Many researchers have questioned how it is that Japanese firms have been able to form these very stable relationships in which buyers and suppliers continue to deal with each other for decades. The data suggest that assemblers very often ensure that their suppliers do not take advantage of long term relationships the old-fashioned way: they own them. One of the striking features of these groups is the high degree of corporate ownership by the assemblers in the parts suppliers. Table 5 presents evidence on seventeen such groups of large assemblers. What is most striking in the table is the degree of ownership held by the lead group firms in the affiliated companies. It is important to remember that this table simply is expressing average ownership positions: there are cases where assemblers do not own a large share of their affiliates. For example, out of the 127 first tier Hitachi affiliates, there are three suppliers that have no shares owned by Hitachi. 24 These sorts of firms become more frequent when you add in the smaller firms that supply the affiliates and form the full Hitachi group, but often that is because they are owned by firms that are largely owned by Hitachi.

The high degree of ownership within these groups raises the question of why Japanese firms do not simply vertically integrate. There are many efficiency arguments for why a firm might not want to do this, but let's ignore them in order to focus on the role of government policy. In Table 5, we see that slightly over half of all firms in the selected vertical groups were capitalized at under $¥ 100$ million in 1992 . Because the selected groups contain some of the largest firms in Japan and large firms tend to have large suppliers, it is likely that for the economy as a whole an even greater share of vertical group members is comprised of small firms. Table 6 presents evidence on

\footnotetext{
${ }^{23}$ It is ironic that Americans refer to these groups by the Japanese word, "keiretsu," but Japanese refer to these groups with the English word "group" ("Guruupu" in Japanese pronunciation).

${ }^{24}$ First tier suppliers are only those suppliers that have relationships with Hitachi directly. Table 5 also includes firms that are affiliated with Hitachi's suppliers.
} 
the size breakdown of the members of manufacturing groups for a much broader sample of firms. Unfortunately, capitalization data are difficult to come by for this sample, but data on the number of employees is readily available. ${ }^{25}$ These data suggest that even if we exclude firms with no employees or those for whom data are unavailable, three quarters of the members of Japanese vertical groups have less than two hundred employees. This number is probably closer to $84 \%$ if one considers that the firms who do not report data are most likely small.

The size of these firms is relevant when one considers the vast array of policies in place in Japan to assist small and medium-sized enterprises (SMEs). While the definition of what constitutes an SME varies somewhat by industry and by government program, according to the Corporate Tax Law, firms that are capitalized at less than $¥ 100$ million and report earnings of less than $¥ 8$ million are SMEs. In practice, this last requirement is generally not binding. For example, according to the Japanese tax agency, the average firm capitalized between $¥ 50$ million and $¥ 100$ million had average earnings of $¥ 5.6$ million yen in 1993 , well within the upper bound. These firms typically report very low average earnings because they are allowed to file "blue returns." Filing a blue return enables them to carry forward losses for up to 5 years and carry them back one year, take special depreciation allowances, and, most importantly, the ability of the government to audit their books is severely circumscribed ${ }^{26}$ In other words, it is probably not too outrageous to say that in Japan only very poorly managed small firms report profits! ${ }^{27}$

It is important to remember, however, that firms that can legally be classified as small are not necessarily small by conventional standards. Because capitalization is a poor measure of firm size, especially for firms that grow through debt or retained earnings, often quite large suppliers

\footnotetext{
${ }^{25}$ Actually, capitalization numbers are available but data analysis would require the entry by hand of over 25,000 capitalization numbers to obtain the sample statistics.

${ }^{26}$ In principle, the books of a firm filing a blue return can only be audited if the authorities catch a calculation error [See Income Tax Act Section $155 \mathrm{~A}$ and B and Corporate Tax Law Section 130]. These and other advantages are discussed in An Outline of Japanese Taxes, p. 127.

${ }^{27}$ While $53.1 \%$ of all firms capitalized under $¥ 100$ million reported a loss in 1992, only $30.5 \%$ of larger firms did. In the category of firms capitalized under $¥ 1$ million, a whopping $67 \%$ reported a loss [National Tax Agency]. All of the difference is not due to tax evasion, however. Part of the reason why larger firms report losses less frequently reflects the fact that the profits of large firms are an average of profitable and unprofitable sections.
} 
can qualify as small firms. ${ }^{28}$ For example, virtually all of the firms capitalized in the $¥ 50$ - 100 million range in the Hitachi group had over 200 employees and one had over a thousand. Because the government has been slow to adjust the criteria for classifying firms as small, in the 1970s it was even easier for larger firms to qualify as small firms. For example, in 1970 the capital criterion for being an SME was the same as it is today, but at that time a firm capitalized between $¥ 50$ million and $¥ 100$ million on average and employed 222 workers as opposed to an average of just over 100 today. ${ }^{29}$ This implies that older suppliers are more likely to be classified as small firms than newer ones. Indeed, because of this historical legacy, probably about $70-80 \%$ of all group members are capitalized at under $¥ 100$ million.

If a firm can be classified as an SME, it is eligible for far more tax breaks and subsidies than in most other industrialized countries. For example, while the Japanese corporate tax rate for earnings of over $¥ 8$ million is $37.5 \%$ (which is the marginal rate for most large companies), the tax rate for earnings of $¥ 8$ million and under is only $28 \% .{ }^{30}$ According to the MOF, this makes the Japanese corporate tax schedule more progressive than that in UK, France, and Germany. ${ }^{31}$ The US, however, has significant tax reductions for firms with earnings of less than $\$ 75,000$, but consolidated reporting makes it more difficult for a firm to organize itself as a collection of smaller enterprises. ${ }^{32}$ Japanese consolidated reporting of financial statements did not begin until 1977, but major loopholes allow firms to create dummy corporations in order to evade Japanese taxes.

One of the most important loopholes is the fact that the Japanese Corporate Tax Law does not distinguish between small enterprises which are wholly owned subsidiaries and those that are

\footnotetext{
${ }^{28}$ Since capitalization is the number of shares times the par value of the shares, it has almost no relationship to firm size for older companies.

${ }^{29}$ While the capitalization criterion has been the same since at least as far back as 1967 , the earnings criterion has been steadily raised from $¥ 3$ million in 1967 to $¥ 8$ million in 1981 [ZKTG, SZ, p. 75].

${ }^{30}$ Neither number includes prefectural, city, or enterprise taxes which tend to increase the differential.

31ZKTG: Sozei Tokushu (1995, p. 76)

${ }^{32}$ US law requires consolidated tax reporting when firms are over $80 \%$ owned by a parent, other members in a corporate group, or if the parent has $80 \%$ of the voting power (Code Sec. 1504(a)). While this provides a tax incentive for US firms to spin off $80 \%$ owned subsidiaries the tax incentives are probably smaller in the US than in Japan. First, US taxes are considerably less progressive than Japanese taxes when one includes state and prefectural taxes for firms with earnings over $\$ 50,000$. This tends to decrease the incentive to spin off subsidiaries. Second, US law requires that outside investors would have to be part of any subsidiary that was spun off for tax purposes. The requirement that outside investors hold some shares may result in unacceptable releases of information or control that offset the gains from forming a vertical group.
} 
not. ${ }^{33}$ This provides firms with an tremendous tax incentive to spin off subsidiaries that are taxed at much lower rates. In addition, this also may help explain why foreign companies often complain that Japanese firms buy from their affiliated companies even if the price is not competitive. If the affiliate is taxed at a lower rate than the parent, it makes sense to try to record as much profit as possible in the affiliate. Unless the affiliate is so inefficient that the cost of production exceeds the outside price by more than the tax subsidy, assemblers should rely on their affiliates even if the outside price is lower.

In addition to these tax measures, there are at least twenty other laws that create a variety of other benefits for SME’s. For example, SME’s borrowed approximately ¥30 trillion in low interest loans in 1994 from the Small Business Finance Corporation, the People's Finance Corporation, and the Central Bank for Commercial and Industrial Cooperatives. ${ }^{34}$ In fact, lending by these government institutions accounted for approximately $10 \%$ of all lending to SME's. This, of course, does not include loans from other public financial institutions, worker training subsidies, subsidies for technological development, and various measures for "structural adjustment assistance."

The second major loophole is that subsidiaries are allowed to have different taxable years than their parents. ${ }^{35}$ This is true even for firms that do not qualify as SME's. For example, while none of Toyota's first tier suppliers would qualify as SME's, only one of these suppliers closed its books on the same date as Toyota did in 1994. Even subsidiaries that were $100 \%$ owned by Toyota closed their books on different dates. Allowing subsidiaries to close their books on different days from their parents permits firms to manipulate tax payment schedules in order to reduce their tax burden. For example, an assembler might pay off its suppliers prior to closing the books in order to reduce its profits and therefore its tax liability. If the supplier then incurred the

\footnotetext{
${ }^{33}$ This is not true of all other laws. Some laws require small firms to have fewer than a certain number of workers (usually 300), not more than one half of their capital from a large firm, and/or not more than one half of their directors from a large firm. These laws are summarized in Chusho Kigyo-cho (1994).

${ }^{34}$ Budget Bureau.

${ }^{35}$ I am grateful to Gary Saxonhouse for suggesting that I explore this possibility.
} 
costs of producing and delivering the parts before its books closed, the group can succeed in delaying its tax payment.

Tax incentives not to vertically integrate are an even stronger incentive in distribution. In addition to the disincentives to open large stores in Japan generated by the Large Scale Retail Law, Japanese tax law grants large advantages to small retailers and wholesalers. ${ }^{36}$ Consider the direct tax benefits: first, all of their tax burden is reduced from $37.5 \%$ to $28 \%$, and second, small stores do not need to charge the $3 \%$ consumption tax. If firms' income stands at around $10 \%$ of sales, then these two measures mean that small retailers in Japan have a 4 percentage point price advantage over their larger counterparts before one even begins to count all the other subsidies and policies available to them as SME's. The existence of these tax incentives suggests that small stores may remain a feature of Japanese retail regardless of the future of the Large Scale Retail Law.

It is important not to conclude from these examples that the tax code is the only reason for vertical groups in Japan. Japan's ban on holding companies probably plays an important role in favoring vertical groups relative to conglomerates. Obviously, there are many other reasons why firms choose not to vertically integrate in both Japan and the US, and there are a lot of members of corporate groups for whom these benefits do not apply. For example, virtually all members of the Nissan and Isuzu groups are large firms with the same closing date as their parents. However, in both groups the affiliate with the largest number of employees closes its books on a different date than its parent. Defenders of the tax code would argue that these large affiliates, Unisia Jecs (in the case of Nissan) and Zexel (in the case of Isuzu), are independent companies, but the fact that they are 30 and 20 per cent owned by their respective buyer firms makes this independence less clear.

Furthermore, newly created affiliates are required to have the same closing date as their parents. In other words, while these policies for SME's historically may have greatly contributed to the formation of vertical groups, their importance for the future is beginning to wane. In fact, the rate of creation of new affiliates has fallen sharply over the last decade, but it is difficult to tell how

\footnotetext{
${ }^{36}$ The Large Scale Retail Law is essentially a zoning restriction that has made it more difficult for large stores to open up new branches. Recent reforms to the law following the Structural Impediments Initiative have reduced these restrictions to some degree.
} 
much of this is due to the recent economic downturn and how much is due to the reduction in incentives to form these organizations.

\section{Reexamining the Link between FDI and Cross-Shareholding}

The discussion, so far, helps to identify how conventional government policies helped shape the structure of corporate ownership in Japan. Tax policies favored certain financial institutions and industrial structures. When this was combined with regulations that limited or eliminated certain types of price competition, Japanese economic agents circumvented these regulations through distinctive forms of shareholding. While these arguments work well to explain levels and trends, they do not explain the shifts in trends that occur roughly between 1965 and 1973. Since it was these movements that motivated the initial argument in favor of a link between FDI and cross-shareholding, it is important that we examine this period in greater detail.

The story begins in 1963 when, following a rapid rise in stock prices, there was a crash in the Japanese market. ${ }^{37}$ Between April and December of 1963 the average share price on the first section of the Tokyo Stock Exchange fell by $27 \%$. Many firms and individuals lost money, which prompted the MOF and the Bank of Japan to decide that it was necessary to prop up the market. Early in 1964, the Japanese government formed a public/private venture called the Japan Joint Securities Corporation (Nihon Kyodo Shoken Kabushiki Gaisha) which had the mission to put a floor on the Japanese market by buying up securities whose prices were "too low." Initially, this firm was financed by private sector banks and low interest loans from the Bank of Japan although as time went on and the firm needed more capital, insurance companies were asked to participate as well.

\footnotetext{
${ }^{37}$ I am indebted in part to Paul Sheard for suggesting that I explore this direction. Much of the material for the discussion of the stock market bailout was drawn from Sheard, 1986.
} 
The Joint Securities Corporation began purchasing securities at a tremendous rate. In its first year of operation, it purchased 1.6 billion shares at a cost of 190 billion yen. ${ }^{38}$ This accounted for $2 \%$ of all shares and $3 \%$ of the entire value of the market. Very quickly, however, it became apparent that this was not sufficient to put a floor on the market. In 1965, Yamaichi securities as well as the smaller Oi (now Wako) securities failed. A large number of other securities companies were also in trouble because, like Yamaichi and Oi, they had used the equity in their trust accounts as collateral to borrow heavily from banks in order to finance the purchase of more stocks. With the slump in stock prices, these firms were no longer solvent [Adams and Hoshii, p. 171]. In order to stave off a new rash of bankruptcies, the BOJ extended $¥ 28$ billion in low interest loans to Yamaichi and another $¥ 5.3$ billion to Oi via city banks. In addition, a second semi-governmental institution, the Japan Securities Holding Association (Nihon Shoken Hoyu Kumiai), was formed to prop up share prices further. By July of that year this association had purchased an additional $¥ 230$ billion in equities from investment trusts and securities companies.

In the end these two institutions purchased $5.2 \%$ of all shares listed on the TSE and the BOJ estimates that the overall cost of the intervention was close to $¥ 500$ billion. However, since the Japan Joint Securities company was restricted to only purchasing equity from the first section of the exchange, where most core corporate group firms are listed, ownership of the first section was probably closer to 6\% [Adams and Hoshii (1972) p. 199]. The government also created various less visible incentives for firms to buy up securities through the extension of loans from the BOJ to banks. For example, between 1964 and 1970 the value of new shares purchased by Japanese banks increased by approximately the same amount as the increase in money lent to them by the BOJ.

Purchasing $6 \%$ of the market had the desired effect on stock prices, but now the semigovernmental institutions faced the problem of what they were going to do with the shares they had purchased. The express objective of the government was to transfer the shares into "stable" holders [Adams and Hoshii p. 199] which meant that these shares would be transferred directly to

\footnotetext{
${ }^{38}$ Nihon Kyodo Shoken Zaidan (1978).
} 
corporations that would not sell them in the short term. Indeed, $90 \%$ of the shares held by the Japan Securities Holding Association and $75 \%$ of the shares held by the Japan Securities Holding Association were sold to corporations during the next five years [Moriki (1988) p. 395]. The sales of these securities probably account for a large portion of the faster increase in non-financial corporate ownership over the late 1960's. In other words, Japanese banks and firms bought more shares because the government subsidized their purchase through low interest lending.

This intervention is probably more important than other legal changes over the period. For example, Mason (1992) argues that one reason for the continued rise in non-financial corporate ownership between 1966 and 1973 was changes in the laws covering private placement of securities. Private placements are private sales of equity, often at very low prices, to selected persons or firms such as directors, employees, suppliers, or distributors. ${ }^{39}$ These transfers are often made to corporate shareholders who are unlikely to sell in response to a takeover bid. Alternatively, they can also be seen as a payment mechanism. In 1966, Mason argues, the Japanese commercial code was changed in order to make these transactions easier. ${ }^{40}$ In order to block a third-party allocation that was proposed by management, two thirds of the existing shareholders would have to vote against it. ${ }^{41}$ Ostensibly the reason given by the firms was to reduce the chance of foreign takeovers, but in practice these sales may have enriched the recipients of the stock and enabled management to become further entrenched. Following a rapid increase in these private placements in the early 1970 's, the securities industry finally clamped down on private placement transactions in 1973.42

This story while initially sounding compelling, probably only explains a small part of the increase in cross-shareholding for several reasons. First, many of the private placements that occurred in the 1950's and 1960's were made by companies whose stock was not trading publicly. In many of these cases, existing shareholders had preemptive rights which meant that they had the

\footnotetext{
39Japan Securities Market Research Institute (1994).

40 Mason (1992), p. 205.

41 Adams and Hoshii (1972) p. 193.

${ }^{42}$ Japan Securities Market Research Institute (1994).
} 
option to stock issued to third parties at the same price. ${ }^{43}$ In addition, since a below market value issuance of stock to a third party would violate the board's duty of loyalty to the shareholders, whether the board approved the sale or not, existing shareholders could block an issuance that harmed them. This makes it unlikely that many issuances were made at prices that were below the true value of the stocks. It is not just legal issues that would have made it difficult for Japanese managers to use private placements to sidestep existing shareholders. The data also does not seem to support this hypothesis. Figure 2 shows the value of private placements relative to equity outstanding as well as the value of the placement over the par value of the stock relative to the amount of money raised by the placement. Since par values are typically substantially below market values, this last measure gives some indication of the discount of the shares. A few things are apparent from the graph. First, while private placements were made at significant discounts prior to 1972 , in later years they were conducted at prices that were substantially above the par value of the stocks. Second, despite the legal change, private placements did not increase much between 1966 and 1973 relative to the total market. Third, although there was a surge in private placements in 1971 and 1972, the magnitude of these placements was minute relative to the size of the market. Even if we assume that these shares were released at half their market value and that all private placements went to corporations (both of which are generous assumptions), then these issues still could only account for no more than 5-10\% of the increase corporate shareholding in the first two years of the decade and even less overall.

The most plausible explanation for the rise in 1972 probably has nothing to do with government policy at all. 1972 was the year in which the TSE posted its single largest percentage gain over the last 30 years. With stock prices at a record high, 498 firms, close to $1 / 3$ of all listed firms, issued equity at a total value of over one trillion yen. This constituted a $4 \%$ increase in the value of the TSE: another 30 year record. Out of the approximately 500 share issuances in that year, however, only 43 were private placements. The vast majority of issuances in both value and number were public offerings or offers to existing shareholders. Since the majority of the shares

\footnotetext{
${ }^{43}$ I am grateful to Mark Ramseyer for clarifying the legal issues related to this first point for me. Technically, existing shareholders were limited to purchasing up to their percentage interest in the new company.
} 
issued in 1972 were offered to the public, in most cases foreigners or any existing shareholders could have just as easily purchased the shares as particular Japanese firms. The notion that crossshareholding grew in these years through quiet side deals does not seem to be born out by the data. On the contrary, the Japanese government played an important and active role in the formation of corporate groups through conventional policies that subsidized their formation.

\section{Conclusion: Towards a Process Oriented Policy}

One is tempted in this type of analysis to draw comparisons with the US and argue that the difference between the two systems is due to Japanese regulation. It is often taken for granted that the US system of diversified ownership of corporations is the "deregulated" benchmark against which other countries should be judged. Indeed, many a proponent of the Japanese keiretsu system has run up against the economists' retort, “ if Japanese corporate groups are so good, why don't we see them develop in the US?" The answer, it turns out, has to do largely with US securities market regulations that have the opposite effect of Japanese regulations: US laws tend to force high levels of diversification by large US financial institutions.

Table 7 [drawn from Roe (1990)] presents the major restrictions on portfolio choices by US financial enterprises. Very little comment is needed. The reason why financial firms do not take out large positions in individual firms and try to actively manage them is that in most cases it would be illegal or tax disadvantaged. Furthermore, joint actions by financials that would involve pooling their shareholdings are also difficult to accomplish due to other regulations. ${ }^{44}$ In light of these restrictions, it is entirely possible that high levels of equity holdings by a single financial entity, as often happens in Japan, may be more the result of free market factors than the atomistic holdings more common in the US. In other words, maybe the problem is not that Japanese regulations make takeovers too difficult, but that US regulations make them too easy!

\footnotetext{
${ }^{44}$ These are discussed in greater detail in Roe (1990). The problematic tegulations covering group action include filing papers ahead of time regarding the intentions of the joint action, restrictions on communications within the group, and restrictions on short term sales by group members.
} 
There is little doubt that Japan is not going to privatize the post office or eliminate tax perks for various financial institutions and small businesses overnight. However, it is also important to recognize that there is increasing pressure within Japan to make these changes. Often foreign pressure, gaiatsu, can be helpful for the proponents of economic liberalization especially when these liberalizations play one political group or ministry off against another. It is along these fault lines - areas where politically powerful constituencies hold opposing views - that US policy is likely to be most effective.

Consider the potential for pressure on Japanese corporate tax rates. Currently, in Japan it is not only foreign firms that would prefer lower corporate tax rates, the leading enterprise organization, Keidanren, has also been engaged in an ongoing battle to lower Japanese corporate tax rates. Japanese firms feel that high corporate taxes hurt them relative to foreign competitors. These forces have successfully reduced the maximum corporate tax from $42 \%$ in 1981 to $37.5 \%$ today. The lowest tax bracket has only fallen from $30 \%$ to $28 \%$ over the same time period. If Japan were to further lower the tax rate for large corporations, that would tend to increase FDI, reduce Japan's trade surplus, stimulate investment, and diminish the incentives for vertical groups. Not bad for a simple process oriented policy.

Pressuring for deregulation in insurance is another potentially high impact area. Considering the vast array of regulations in the US market, this would have to be a bilateral negotiation at the very least, but there certainly is strong support within Japan for deregulation here, too. In the framework talks progress was made on easing the acceptance of new insurance products, reducing insurance rate regulations, and the introduction of insurance brokers, but clearly this is an area where more could be done. For example, the innovative Japanese insurance companies, banks and the MOF are not happy with the "competition" offered by the MPT and other government institutions. Once again this provides a potential area for mutual gain.

Deregulation of investment vehicles is a further area that might work to improve Japanese efficiency and diminish the importance of corporate groups. The MOF restrictions on the types of funds that can manage tax-free investments and the portfolios of these firms seem unnecessary. 
The argument that without MOF guidance, firms will invest in risky assets seem hollow in light of MOF regulations that required that firms invest in the now depressed real estate sector. Deregulation in this area is likely to have wide ranging impacts on the structure of corporate ownership in Japan.

This list of potential process oriented policies is only a small sample of those that are likely to have profound effects on the structure of Japanese industrial organization. The US has a clear interest in Japanese efforts to deregulate their financial markets. It is a shame that the US ends up talking about numerical targets instead. 


\section{Bibliography}

Adams, T.F.M. and Iwao Hoshii (1972) A Financial History of the New Japan. Tokyo: Kodansha International Ltd.

American Chamber of Commerce in Japan / Financial Services Committee (1993) Insurance Sector Report 1993: A Study of Japanese Insurance Procurement Practices within Keiretsu Groups. Tokyo.

Aoki, Masahiko and Hugh Patrick ed. (1994) The Japanese Main Bank System. New York: Oxford University Press.

Bank of Japan. Economic Statistics Annual. Tokyo: Bank of Japan, various issues.

Booz, Allen \& Hamilton, Inc. (1987) Direct Foreign Investment in Japan: The Challenge for Foreign Firms.

Budget Bureau, Ministry of Finance (1995) The Japanese Budget in Brief.

Carroll, J. (1994) "The Not-So-Brave New World of Japanese Insurance: To Liberalize or Not to Liberalize," mimeo.

Economics of Distribution Research Institute[Ryutsu Keizai Kenkyujo] Ryutsu Tokei Shiryoshu [Book of Distribution Statistics]. Tokyo: Ryutsu Keizai Kenkyujo, various issues.

Encarnation, D. (1992) Rivals Beyond Trade: America versus Japan in Global Competition, Ithaca: Cornell University Press.

Encarnation, D. and M. Mason (1990) "Neither MITI nor America: the Political Economy of Capital Liberalization in Japan," International Organization, 44, 1, pp. 25-54.

Federation of Bankers Associations of Japan (1994) The Banking System in Japan. Tokyo: Zenginko [Federation of Bankers Associations of Japan].

Gerlach, M. (1992) Alliance Capitalism, Berkeley: The University of California Press.

Graham, Edward M. and Paul Krugman (1989) Foreign Direct Investment. Washington, D.C.: Institute For International Economics.

Graham, Edward M. and Paul Krugman (1993) "The Surge in Foreign Direct Investment in the 1980s," in Froot, Kenneth A. ed. (1993) Foreign Direct Investment. Chicago: University of Chicago Press.

Ishi, Hiromitsu (1993) The Japanese Tax System Second Edition. New York: Oxford University Press.

Ito, T. (1992) Shohisha Jushi no Keizaigaku [Consumer Centered Economics] Tokyo: Nihon Keizai Shimbunsha.

Ito, T., and M. Maruyama (1991) "Is the Japanese Distribution System Really Inefficient?" in Krugman P. ed., Trade with Japan: Has the Door Opened Wider? Chicago, The University of Chicago Press. 
Japan Securities Research Institute (1994) Securities Market in Japan 1994. Tokyo: Japan Securities Research Institute.

Julius, D. and S. Thomsen (1988) "Foreign-owned Firms, Trade, and Economic Integration," Tokyo Club Papers 2, Royal Institute of Economic Affairs.

Lawrence, R. (1993) "Japan's Low Levels of Inward Acquisitions: The Role of Inhibitions on Acquisitions" in Froot, K. ed. Foreign Direct Investment, The University of Chicago Press.

Mason, M. (1992) American Multinationals and Japan: The Political Economy of Capital Controls, 1899-1980.

Matsuoka, M. and B. Rose (1994) The DIR Guide to Japanese Economic Statistics, New York: Oxford University Press.

McKenzie, C. (1992) "Stable Shareholdings and the role of Japanese Life Insurance Companies," in Sheard, Paul ed. International Adjustment and the Japanese Firm, St. Leonards: Allen \& Unwin.

Ministry of Finance [ZKTG] (1993) Zaisei Kinyu Tokei Geppo, [Public Finance and Monetary Monthly Statistics] Tokyo: Okurasho Insatsu Kyoku [Ministry of Finance Printing Bureau], various issues.

Ministry of International Trade and Industry. Gaishikei Kigyo no Doko [Foreign Firm Trends], Tokyo: Okurasho Insatsu Kyoku, various issues.

Moriki, A. and S. Isozaki eds. (1988) Okurasho hyaku-nijunenshi, [The 120 Year History of the Ministry of Finance] Tokyo : Keizai Konwakai.

National Tax Agency. Kokuzeicho Tokei Nenposho [National Tax Agency's Yearly Statistical Data Book]. Tokyo, various issues.

Nihon Kyodo Shoken Zaidan, (1978)Nihon Kyodo Shoken Kabushiki Gaisha Shi, [History of the Japan Joint Securities Company] Tokyo: Kyodo Insatsu Kabushiki Gaisha.

Nishimura, K. (1991) "Entry Barriers, Monopoly Profits and Production Efficiency: The Case of Japanese Retail Trade Sector," Dept. of Economics mimeo, The University of Tokyo.

Noland, M. (1992) "Why are Prices in Japan so High?" Department of Economics mimeo, The John's Hopkins University.

Office of the President of the United States (February 1994) Economic Report of the President. Washington, D.C.: United States Government Printing Office.

Patrick, H. and T. Rohlen (1987) "Small-Scale Family Enterprises" in Yamamura, K. and Y. Yasuba ed. The Political Economy of Japan: Volume 1 The Domestic Transformation. Stanford: Stanford University Press.

Ramseyer, J. M. (1987) “Takeovers in Japan: Opportunism, Ideology and Corporate Control," UCLA Law Review, 35.

Roe, M. J. (1990) "Political and Legal Restraints on Ownership and Control of Public Companies," Journal of Financial Economics, 27. 
Sheard, P. (1994) "Interlocking Shareholdings and Corporate Governance in Japan," in Aoki, M. and R. Dore eds. The Japanese Firm: Sources of Competitive Strength, New York: Oxford University Press.

Sheard, P. (1986) "Intercorporate Shareholdings and Structural Adjustment in Japan," AustraliaJapan Research Centre Research Paper No. 140.

Shukan Toyo Keizai Rinji Zokan/Data Banku [Weekly Toyo Keizai Special Data Bank]. Gaishikei Kigyo Soran[Compendium of Foreign-Owned Firms], [GKS]. Tokyo: Toyo Keizai, various issues

Shukan Toyo Keizai Rinji Zokan/Data Banku [Weekly Toyo Keizai Special Data Bank] Nihon no Kigyo Guruирu[Japanese Enterprise Groups], [NKG]. Tokyo: Toyo Keizai, various issues.

Shukan Toyo Keizai Rinji Zokan/Data Banku [Weekly Toyo Keizai Special Data Bank]. Kigyo Keiretsu Soran[Compendium of Enterprise Groups], [KKS]. Tokyo: Toyo Keizai, various issues.

Small and Medium Enterprise Agency (1987) Chusho Kigyo Shisaku no Aramashi: Showa 62 Nendohatsu [Outline of the Measures for Small and Medium Enterprises for 1987].

Small and Medium Enterprise Agency (1994) Chusho Kigyo Shisaku Soran [General Survey of Measures for Small and Medium Enterprises].

Tokyo Stock Exchange [TSE] (1994)Shoken Tokei Nenpo [Annual Securities Statistics] Takahashi, Koji ed. Tokyo: Tokyo Shoken Torihikijo Tyosabu [Research Department of the Tokyo Stock Exchange].

Tax Bureau, Ministry of Finance. An Outline of Japanese Taxes . Tokyo: Ministry of Finance Printing Bureau, various issues.

Viner, A. (1988) Inside Japanese Financial Markets. Homewood: Dow Jones-Irwin.

Ministry of Posts and Telecommunications (1994) Yusei Tokei: Heisei 6 Nendohan [Postal Statistics for 1994]. Tokyo: Okurasho Insatsu Kyoku [Ministry of Finance Printing Bureaul.

Weinstein, D. (1995a) "Evaluating Administrative Guidance and Cartels in Japan, 1957-1988" Journal of the Japanese and International Economies, 9.

Weinstein, D. (1995b) "Structural Impediments to Foreign Direct Investment in Japan: What Have We Learned over the Last 450 Years?" in Graham, E. and M. Yoshitomi, eds. Foreign Direct Investment in Japan, Edgar Elgar, forthcoming. 


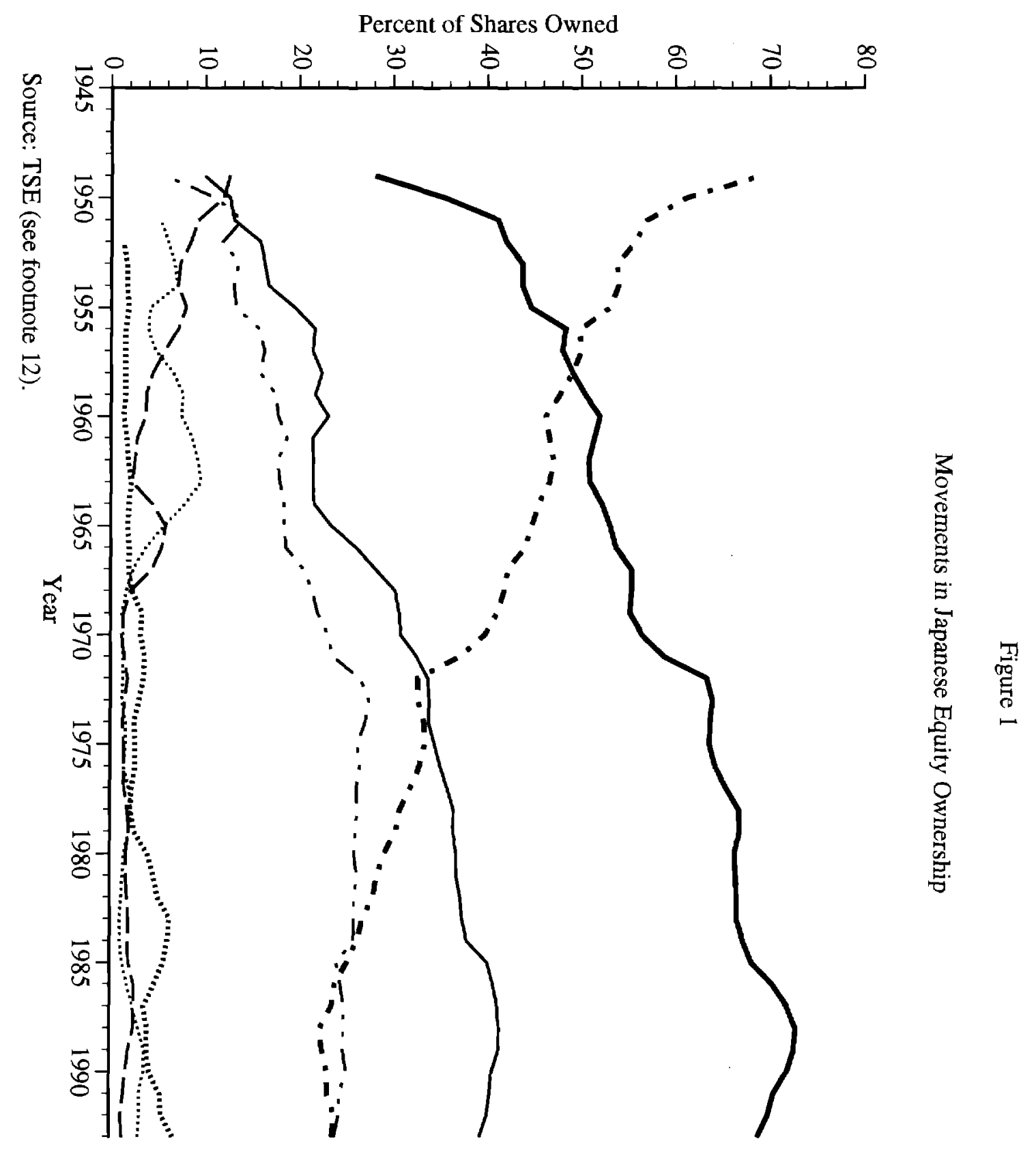

\begin{tabular}{|c|c|c|c|c|c|c|}
\hline$\vdots$ & I & & $\begin{array}{l}1 \\
i\end{array}$ & $\begin{array}{l}1 \\
!\end{array}$ & & \\
\hline 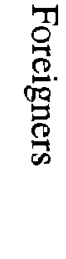 & 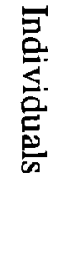 & 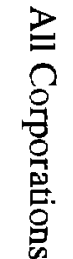 & 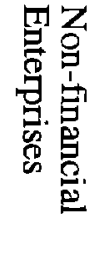 & 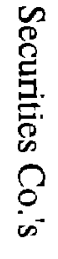 & 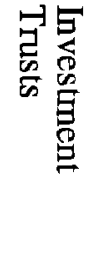 & 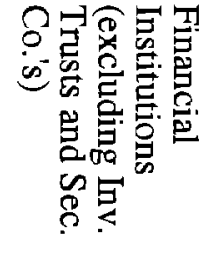 \\
\hline
\end{tabular}


Figure 2

Private Placement of Securities

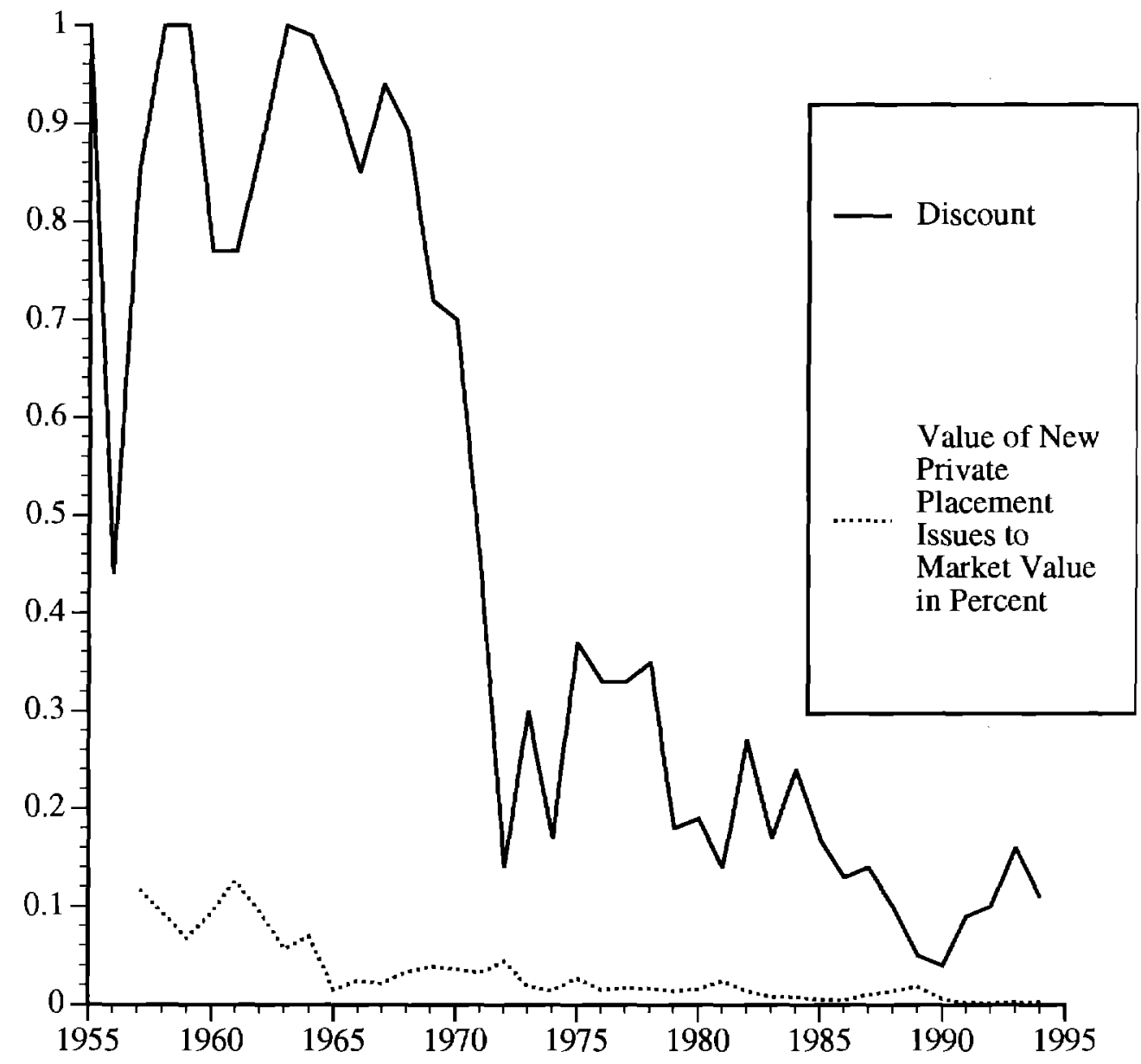

Source: TSE

Note: The discount equals (1 - (Par Value of Private Placements)/(Value of Private Placements)) High discounts imply that the shares were sold at close to par. 


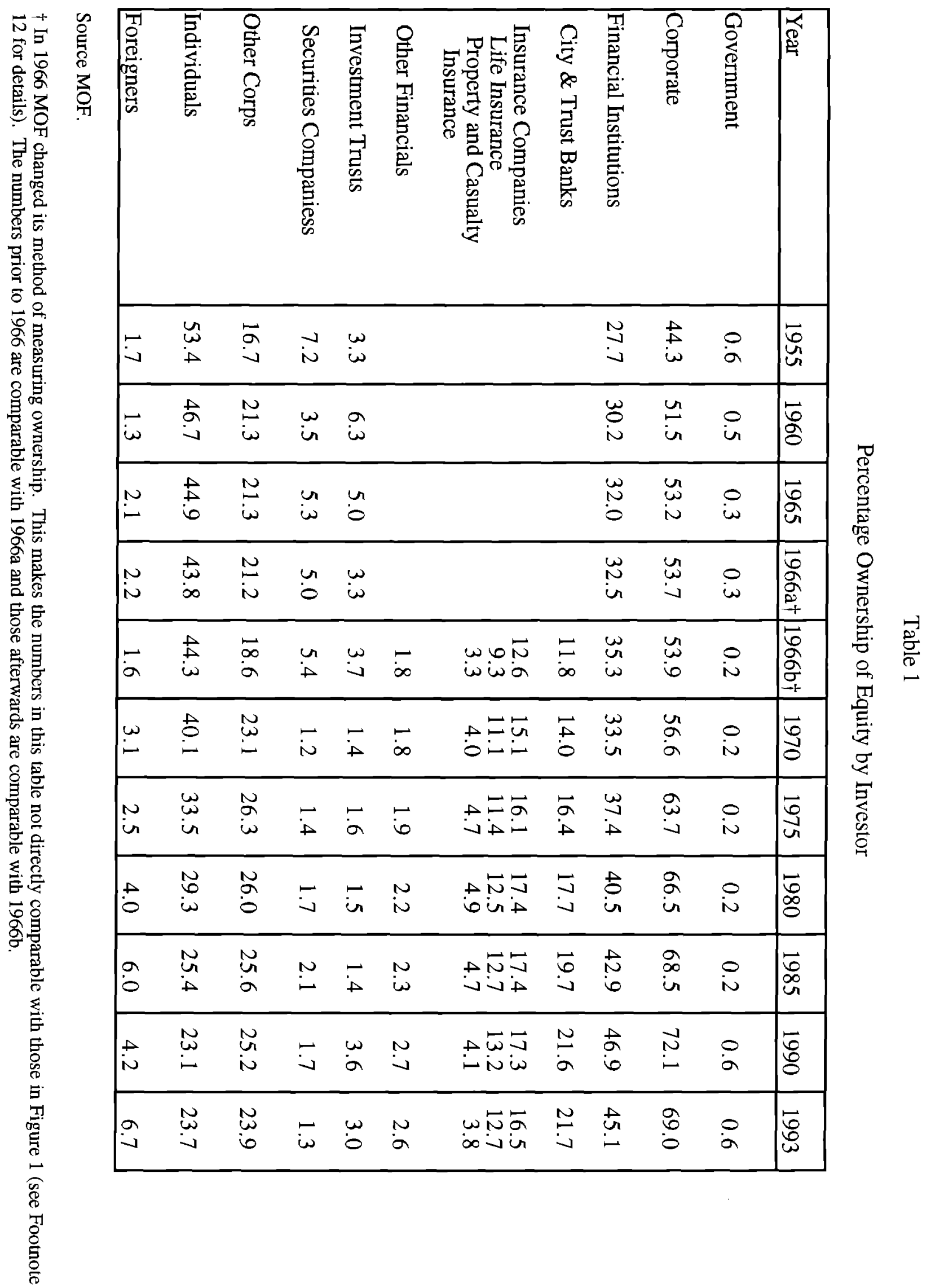



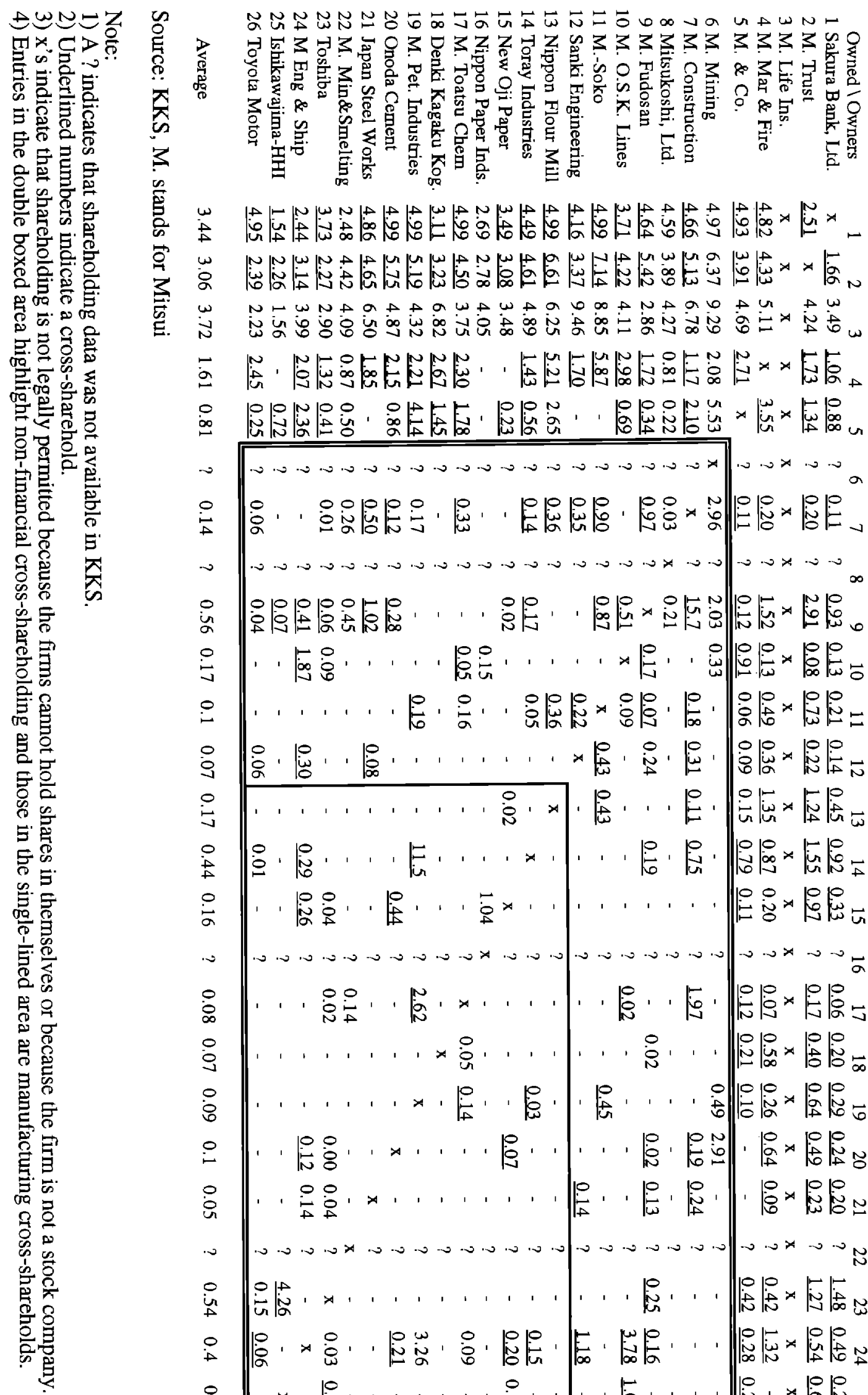

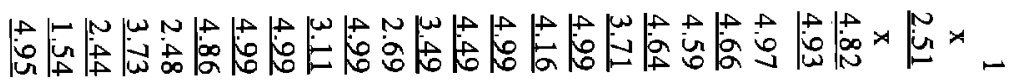

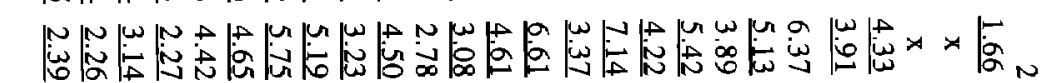
$n+\omega n+a+a \omega+\omega+a \sigma_{0}+N+a b+u+\omega$

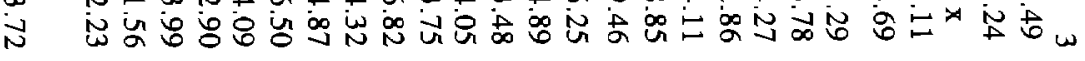

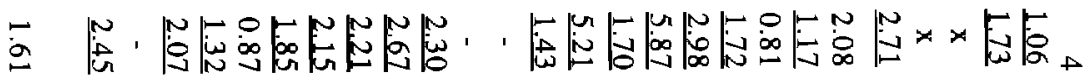

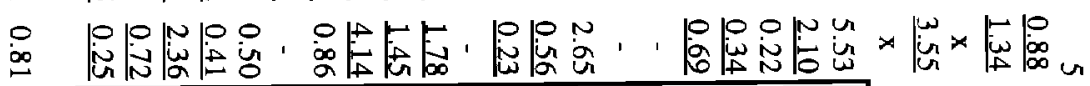

(2)

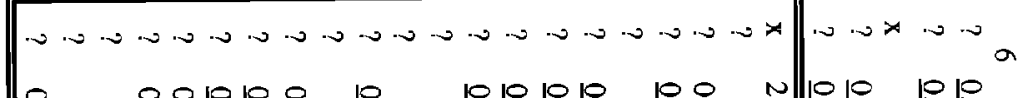

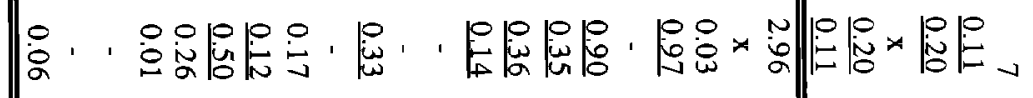
$\sim$ 每

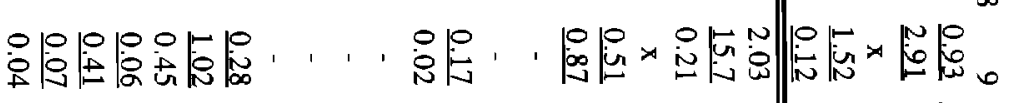
$\stackrel{\circ}{\stackrel{\circ}{*}}$ (1) 웅 , 150

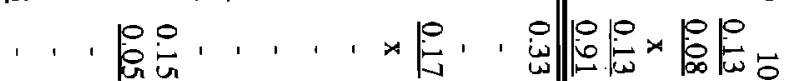

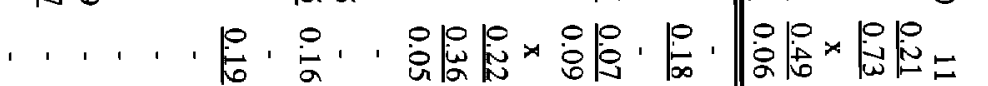

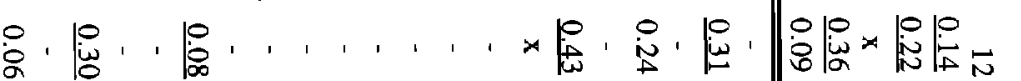
붕

$$
\begin{aligned}
& 0 \\
& 0 \\
& 0 \\
& i \\
& 0 \\
& \dot{0} \\
& 0 \\
& 0 \\
& ن \\
& \dot{4} \\
& \circ \\
& 0 \\
& 0 \\
& 0
\end{aligned}
$$$$
\text { i }
$$$$
\text { in }
$$

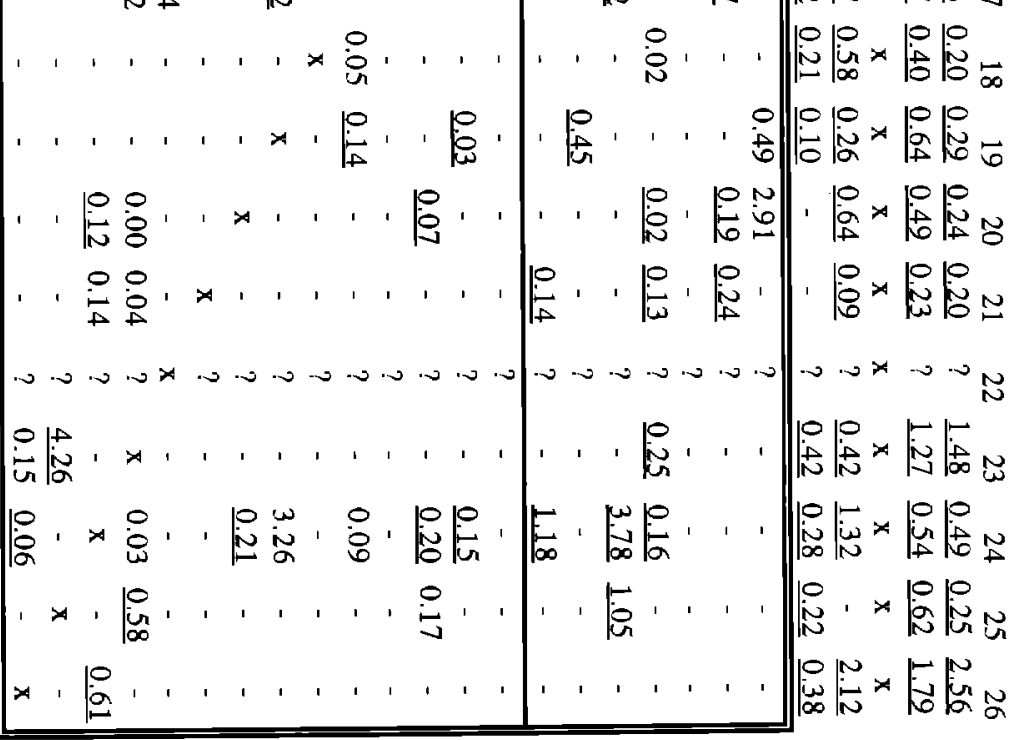

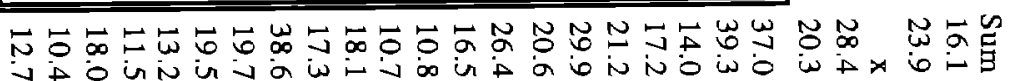


Table 3

Mitsui Group Insurance Business (1991)

\begin{tabular}{|c|c|c|c|c|}
\hline Core Company & Case Agents & $\begin{array}{l}\text { Insurance } \\
\text { Companies }\end{array}$ & $\begin{array}{l}\text { Estimated } \\
\text { Share of } \\
\text { Insurance }\end{array}$ & $\begin{array}{l}\text { \% of } \\
\text { Insurance } \\
\text { Company } \\
\text { Shareholding } \\
\text { in Core } \\
\text { Company }\end{array}$ \\
\hline \multirow{5}{*}{ Sakura Bank } & \multirow{2}{*}{ Yowa } & Mitsui M\&F & 25 & \multirow[t]{5}{*}{1.1} \\
\hline & & $\begin{array}{l}\text { Nippon F\&M } \\
\text { Others }\end{array}$ & 75 & \\
\hline & Horai & $\begin{array}{l}\text { Mitsui M\&F } \\
\text { Other } 18 \\
\text { coms. }\end{array}$ & unknown & \\
\hline & \multirow[t]{2}{*}{$\begin{array}{l}\text { Keihanshin Hoken } \\
\text { Daiko }\end{array}$} & $\begin{array}{l}\text { Dowa F\&M } \\
\text { (main) }\end{array}$ & over 50 & \\
\hline & & $\begin{array}{l}\text { Mitsui M\&F } \\
\text { Others }\end{array}$ & unknown & \\
\hline $\begin{array}{l}\text { Mitsui Trust } \\
\text { Banking }\end{array}$ & Sanshin Shinko & $\begin{array}{l}\text { Mitsui M\&F } \\
\text { Others }\end{array}$ & $\begin{array}{l}90 \\
10\end{array}$ & 1.7 \\
\hline Mitsui Life Ins. & Onyu & Mitsui M\&F & 100 & \\
\hline \multirow[t]{2}{*}{ Mitsui Co. } & \multirow[t]{2}{*}{$\begin{array}{l}\text { Mitsui Co. (Ins. } \\
\text { Div.) }\end{array}$} & $\begin{array}{c}\text { Non-Marine: } \\
\text { Mitsui } \\
\text { M\&F } \\
\text { Other }\end{array}$ & $\begin{array}{l}80 \\
20\end{array}$ & \multirow[t]{2}{*}{2.7} \\
\hline & & $\begin{array}{l}\text { Marine: } \\
\text { Mitsui } \\
\text { M\&F }\end{array}$ & 100 & \\
\hline Mitsui Mining Co. & Sanko Shoji & Mitsui M\&F & 100 & 2.1 \\
\hline $\begin{array}{l}\text { Mitsui Construction } \\
\text { Co. }\end{array}$ & Sanken Shoji & Mitsui M\&F & 100 & 1.2 \\
\hline $\begin{array}{l}\text { Sanki Engineering } \\
\text { Co. }\end{array}$ & Sanshin Sangyo & Mitsui M\&F & 100 & 1.7 \\
\hline $\begin{array}{l}\text { Nippon Flour Mills } \\
\text { Co. }\end{array}$ & Suehiro Kogyo & Mitsui M\&F & 100 & 5.2 \\
\hline \multirow[t]{2}{*}{$\begin{array}{l}\text { Toray Industries, } \\
\text { Inc. } \\
\end{array}$} & \multirow[t]{2}{*}{ Toray Agency } & Mitsui M\&F & nearly 100 & \multirow[t]{2}{*}{1.4} \\
\hline & & $\begin{array}{l}\text { Tokio M\&F } \\
\text { Sumitomo } \\
\text { M\&F }\end{array}$ & & \\
\hline \multirow[t]{2}{*}{ Oji Paper Co. } & Oji Fudosan & $\begin{array}{l}\text { Mitsui M\&F } \\
\text { Others }\end{array}$ & Unknown & \\
\hline & $\begin{array}{l}\text { Kyoei Shokai } \\
\text { (general agt) }\end{array}$ & $\begin{array}{l}\text { Mitsui M\&F } \\
\text { Other } 21 \text { co.'s }\end{array}$ & $\begin{array}{l}45 \\
55\end{array}$ & \\
\hline $\begin{array}{l}\text { Mitsui Toatsu } \\
\text { Chemicals }\end{array}$ & Santo Sangyo & Mitsui M\&F & 100 & 2.3 \\
\hline $\begin{array}{l}\text { Mitsui Petrochemical } \\
\text { Inds., Ltd. }\end{array}$ & Sun Business & $\begin{array}{l}\text { Mitsui M\&F } \\
\text { Others }\end{array}$ & Top share & 2.2 \\
\hline
\end{tabular}


Table 3 (Continued)

\begin{tabular}{|c|c|c|c|c|}
\hline Onoda Cement Co. & Onoda Fudosan & $\begin{array}{l}\text { Mitsui M\&F } \\
\text { Others }\end{array}$ & $\begin{array}{l}90 \\
10\end{array}$ & \multirow[t]{2}{*}{2.2} \\
\hline & Azuma Kogyo & $\begin{array}{l}\text { Mitsui M\&F } \\
\text { Others }\end{array}$ & $\begin{array}{l}90 \\
10\end{array}$ & \\
\hline $\begin{array}{l}\text { The Japan Steel } \\
\text { Works, Ltd. }\end{array}$ & $\begin{array}{l}\text { Fuji Shokai (general } \\
\text { agt) }\end{array}$ & $\begin{array}{l}\text { Mitsui M\&F } \\
\text { Sumitomo } \\
\text { F\&M } \\
\text { Others }\end{array}$ & $\begin{array}{l}80 \\
20\end{array}$ & 1.9 \\
\hline $\begin{array}{l}\text { Mitsui Mining \& } \\
\text { Smelting Co. }\end{array}$ & $\begin{array}{l}\text { Mitsui M\&S staff } \\
\text { service }\end{array}$ & Mitsui M\&F & 100 & 0.9 \\
\hline Toshiba Corp. & Toshiba Ins. Service & $\begin{array}{l}\text { Mitsui M\&F } \\
\text { Nippon } \\
\text { F\&M(main) } \\
\text { Others }\end{array}$ & $\begin{array}{l}30 \\
40 \\
30 \\
\end{array}$ & $\begin{array}{l}1.3 \\
1.9\end{array}$ \\
\hline $\begin{array}{l}\text { Mitsui Engineering } \\
\text { \& Shipbuilding }\end{array}$ & Sanko Zitsugyo & $\begin{array}{l}\text { Mitsui M\&F } \\
\text { Others }\end{array}$ & $\begin{array}{l}80 \\
20\end{array}$ & 2.2 \\
\hline Toyota Motor Corp. & Toyota Tsusho & $\begin{array}{l}\text { Mitsui M\&F } \\
\text { Others }\end{array}$ & Top Share & 2.5 \\
\hline Mitsukoshi, Ltd. & Sanbi & $\begin{array}{l}\text { Mitsui M\&F } \\
\text { Other } 10 \\
\text { coms. }\end{array}$ & $\begin{array}{l}50 \\
50\end{array}$ & 0.8 \\
\hline $\begin{array}{l}\text { Mitsui Real Estate } \\
\text { Development Co. }\end{array}$ & Mitsui R.E.D. Sales & $\begin{array}{l}\text { Mitsui M\&F } \\
\text { Others }\end{array}$ & Top Share & 1.7 \\
\hline $\begin{array}{l}\text { Mitsui O.S.K. } \\
\text { Lines, Ltd }\end{array}$ & Shosenmitsui Kosan & $\begin{array}{l}\text { Mitsui M\&F } \\
\text { Sumitomo } \\
\text { M\&F }\end{array}$ & $\begin{array}{l}50 \\
50\end{array}$ & $\begin{array}{l}3.0 \\
3.1\end{array}$ \\
\hline $\begin{array}{l}\text { Mitsui Warehouse } \\
\text { Co. }\end{array}$ & $\begin{array}{l}\text { Tokyo Sanshin } \\
\text { Service }\end{array}$ & $\begin{array}{l}\text { Mitsui M\&F } \\
\text { Others } \\
\end{array}$ & \begin{tabular}{|l|}
95 \\
5 \\
\end{tabular} & 5.9 \\
\hline Average & & $\begin{array}{l}\text { Mitsui M\&F } \\
\text { All Related } \\
\text { Insurers } \\
\end{array}$ & \begin{tabular}{|l}
88.3 \\
94.4 \\
\end{tabular} & \\
\hline
\end{tabular}

Notes:

Dowa F\&M once belonged to Taiyo-Kobe Bank Group, now merged into Sakura Bank, which holds $4.99 \%$ of the shares of Dowa F\&M.

Sakura's three case agents handle their pre-merged bank's business, Yowa for Taiyo Bank, Horai for Mitsui Bank, and Keihanshin Hoken Daiko for Kobe Bank. 


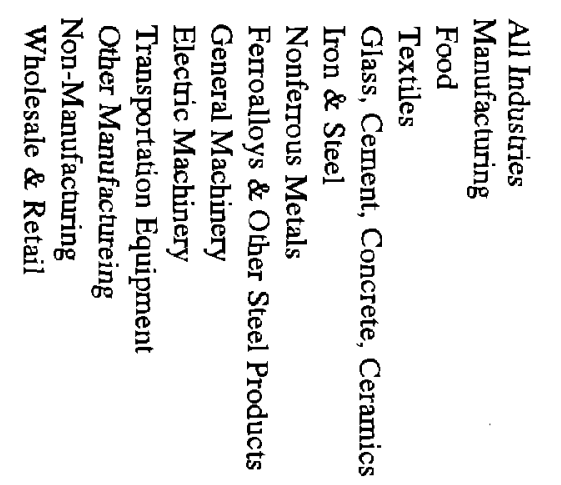

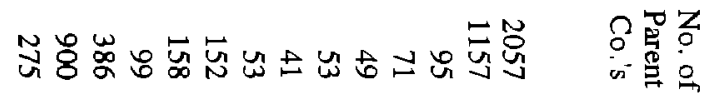

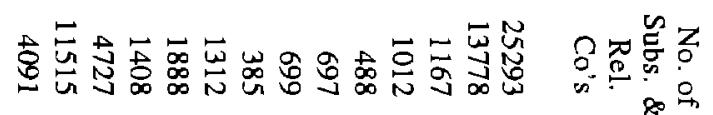

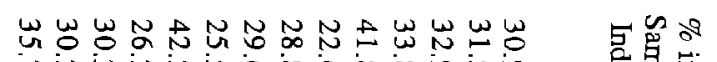

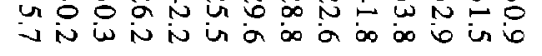

Nัป

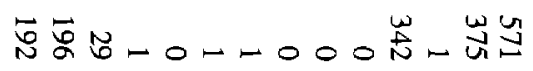

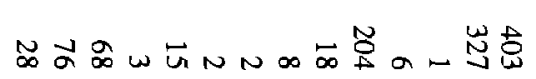

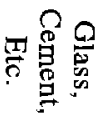

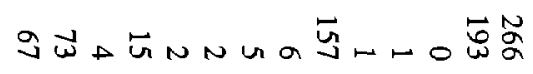

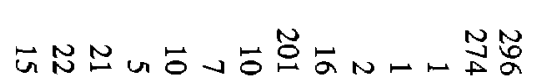

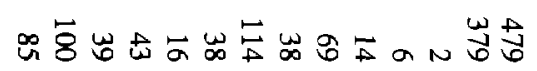

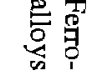

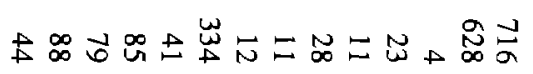

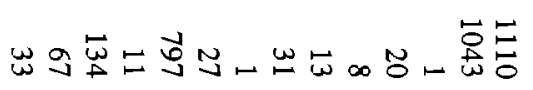
畨号 紫宫 富学常

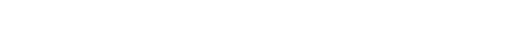
点苔

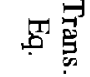

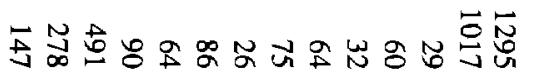

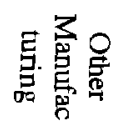

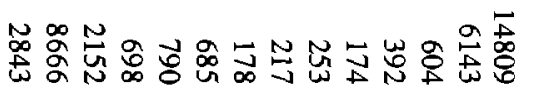
录录

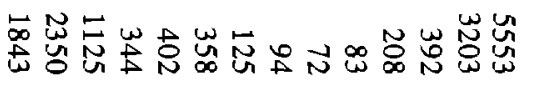
蛋的竞

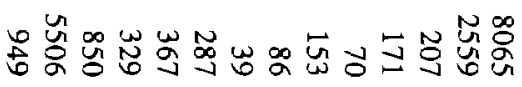


Table 5

Capital Finance of Vertical Group Members in 1984

\begin{tabular}{|c|c|c|}
\hline $\begin{array}{l}\text { Number of } \\
\text { Subsidiaries and } \\
\text { Related }\end{array}$ & $\begin{array}{l}\text { Core Company's } \\
\text { Ave. Lending } \\
\text { Share }(\%)\end{array}$ & $\begin{array}{l}\text { Ave. Percent of } \\
\text { Shares Held by } \\
\text { Core Company }\end{array}$ \\
\hline
\end{tabular}

Percent

Capitalized at under $¥ 100$ mil.*

\begin{tabular}{|c|c|c|c|c|}
\hline Kanebo & 132 & 31.37 & 87.46 & 53.19 \\
\hline Asahi Kasei & 145 & 11.89 & 56.44 & 44.94 \\
\hline Nippon Steel & 150 & 3.51 & 30.34 & 52.79 \\
\hline Nittetsu Steel Pipe & 108 & 5.90 & 66.98 & 60.00 \\
\hline Sumitomo Metals & 104 & 7.89 & 44.74 & 55.39 \\
\hline Kobe Steel & 83 & 3.78 & 34.94 & 55.13 \\
\hline Hitachi & 211 & 7.64 & 70.07 & 59.23 \\
\hline Toshiba & 199 & 9.90 & 74.29 & 55.35 \\
\hline Mitsubishi Electric & 179 & 2.57 & 30.08 & 58.33 \\
\hline Nippon Electrci & 143 & 7.88 & 59.78 & 57.56 \\
\hline Fujitsu & 123 & 12.44 & 76.89 & 46.02 \\
\hline Matsushita Electric & 455 & 15.70 & 78.67 & 37.72 \\
\hline Sony & 87 & 21.70 & 92.77 & 21.67 \\
\hline Mitsubishi Heavy Industries & 132 & 5.22 & 42.55 & 55.41 \\
\hline Nissan & 21 & 24.54 & 74.57 & 61.48 \\
\hline Toyota & 164 & 6.76 & 59.79 & 62.67 \\
\hline Honda & 249 & 19.66 & 89.76 & 21.21 \\
\hline $\begin{array}{l}\text { Average } \\
\text { Source: KKS (1984) and KG }\end{array}$ & $\begin{array}{l}158 \\
* \mathrm{Da}\end{array}$ & 11.67 & 62.95 & 50.48 \\
\hline
\end{tabular}

Table 6

Size Breakdown of Japanese Subsidiaries

\begin{tabular}{|c|c|c|c|c|c|c|c|c|c|c|c|c|}
\hline \multirow[t]{2}{*}{ Industry } & \multirow{2}{*}{$\begin{array}{l}\text { Number of } \\
\text { Workers in } \\
\text { Parent Co. }\end{array}$} & \multirow{2}{*}{$\begin{array}{c}\text { Number of } \\
\text { Workers in } \\
\text { Subs. }\end{array}$} & \multirow{2}{*}{$\begin{array}{c}\text { Total } \\
\text { Number } \\
\text { of Subs. }\end{array}$} & \multicolumn{9}{|c|}{ Percentage of Employees by Firm Size } \\
\hline & & & & $\begin{array}{c}0 \text { or } \\
\text { Un- } \\
\text { known }\end{array}$ & $<30$ & $30-39$ & $40-49$ & $50-99$ & $100-199$ & $200-499$ & $500-999$ & $1000+$ \\
\hline All Industries & $6,279,200$ & $3,976,700$ & 25293 & 13 & 33 & 6 & 5 & 15 & 12 & 10 & 4 & 3 \\
\hline Manufacturing & $3,129,000$ & $1,914,500$ & 8224 & 11 & 21 & 6 & 5 & 17 & 16 & 14 & 5 & 4 \\
\hline Nonmanufacturing & $3,150,200$ & $2,062,200$ & 17069 & 14 & 39 & 6 & 5 & 13 & 10 & 8 & 3 & 2 \\
\hline
\end{tabular}

Source: NKG (1995) 
Table 7

Important Ownership Restrictions for US Financial Institutions

\begin{tabular}{|c|c|c|c|}
\hline Institution & $\begin{array}{c}\text { Assets in } \\
\text { Trillions } \\
(1989) \\
\end{array}$ & Restriction & Source \\
\hline Banks & $\$ 3.2$ & Stock Ownership Prohibited & Glass-Steagall Bank Act \\
\hline $\begin{array}{l}\text { Bank Holding } \\
\text { Companies }\end{array}$ & $\$ 0.3$ & $\begin{array}{l}\text { No More than } 5 \% \text { of the voting stock } \\
\text { of any nonbank }\end{array}$ & Bank Holding Act of 1956 \\
\hline $\begin{array}{l}\text { Bank Trust } \\
\text { Funds }\end{array}$ & $\begin{array}{c}\$ 0.7 \\
(1988)\end{array}$ & $\begin{array}{l}\text { No more than } 10 \% \text { of assets in any } \\
\text { one company } \\
\text { Active bank control could trigger } \\
\text { bank liability to controlled company }\end{array}$ & $\begin{array}{l}\text { Comptroller Regulations } \\
\text { Bankruptcy case law }\end{array}$ \\
\hline Life Insurers & $\$ 1.3$ & $\begin{array}{l}\text { No more than } 2 \% \text { of assets can be } \\
\text { placed in a single company } \\
\text { No more than } 20 \% \text { of assets can be } \\
\text { held in stock }\end{array}$ & $\begin{array}{l}\text { NY Insurance Law (for } \\
\text { insurers doing business in } \\
\text { NY) } \\
\text { NY Insurance Law }\end{array}$ \\
\hline $\begin{array}{l}\text { Property and } \\
\text { Casualty }\end{array}$ & $\$ 0.5$ & None & Same \\
\hline $\begin{array}{l}\text { Open End } \\
\text { Mutual Funds }\end{array}$ & $\$ 0.5$ & $\begin{array}{l}\text { For Half of Portfolio: No more than } \\
5 \% \text { of fund assets can be invested } \\
\text { into stock of any issuer and fund } \\
\text { may not purchase more than } 10 \% \text { of } \\
\text { the stock of any company. For other } \\
\text { half: No more than } 25 \% \text { of funds } \\
\text { assets can be placed in a single stock. } \\
\text { Otherwise tax penalties apply. } \\
\text { Must get SEC approval prior to joint } \\
\text { action with affiliate, i.e., a fund } \\
\text { needs SEC approval before acting } \\
\text { jointly to control a company of which } \\
\text { it and its partner own more than } 5 \%\end{array}$ & $\begin{array}{l}\text { Investment Company Act } \\
\text { of 1940: Subchapter M of } \\
\text { the Internal Revenue Code }\end{array}$ \\
\hline Pensions & $\$ 1.2$ & $\begin{array}{l}\text { Must diversify unless clearly sensible } \\
\text { not to }\end{array}$ & $\begin{array}{l}\text { Employment Retirement } \\
\text { Income Security Act of } \\
1974\end{array}$ \\
\hline
\end{tabular}

Source: Roe (1990) 